\title{
ENABLING CONSTRAINTS: fontes institucionais de Coerência nas políticas públicas no pós-socialismo*
}

\author{
David Stark e Laszlo Bruszt
}

Introdução

Quais são as bases da coerência das políticas públicas em sociedades que experimentam transformações simultâneas de regime político e formas de propriedade? Em contraste com a crença convencional de que executivos não limitados têm mais autoridade para executar reformas, sustentamos, neste artigo, que autoridade e responsabilidade não são contraditórios. Desenvolvemos esse argumento a partir de um estudo comparativo de vários países da Europa Central. $\mathrm{Na}$ primeira seção resumimos algumas das principais diferenças das políticas públicas nos países estudados. A parte principal do trabalho procura explicar as diferenças na coerência dessas políticas na Alemanha, Hungria e República Tcheca. A seção final introduz o conceito de responsabilidade politica estendida ${ }^{\mathrm{I}}$, de forma a elaborar um quadro analítico que nos permita compreender as fontes institucionais do surgimento e da manutenção de políticas sustentáveis de transformação econômica.
Algumas informações sobre políticas econômicas

Em Postsocialist pathways: transforming politics and property in Eastern Europe, desafiamos a visão amplamente difundida de que as opções de políticas para a reestruturação econômica no Leste Europeu pós-socialista estão limitadas à escolha entre mercados fortes e Estados fortes (Stark e Bruszt, 1998).1 Ressaltando que o Leste Europeu carece, historicamente, tanto de mercados fortes como de Estados fortes, sugerimos que o legado de redes fortemente conectadas entre firmas poderia ser um ponto de partida alternativo. Com o termo "redes reestruturantes" colocamos uma dupla questão: (a) como redes de firmas (em oposição à firma isolada e individual) podem constituir a unidade a ser reestruturada? e (b) como instituições de associação deliberativa que não sejam baseadas no mercado ou em hierarquia podem ser agentes da reestruturação econômica? Enfocando os casos da Hungria e da República Tcheca, nossa investigação relacionou mudanças no curso da reestruturação econômica com a forma pela qual os 
administradores públicos levaram (ou não) em conta as propriedades das redes de ativos e passivos. $\underline{\underline{I}}$ Esse reconhecimento (ou não reconhecimento) teve conseqüências importantes na capacidade (ou fracasso) em gerenciar a interdependência dos ativos e as cadeias de passivos nos dois casos.

Embora, de um ponto de vista simplesmente ideológico, pudéssemos ter previsto que os decisores políticos da República Tcheca seguiriam as predições de Adam Smith para "destruir as combinações", eles na verdade levaram em conta as propriedades da rede, adotando políticas ativas antifalência e medidas de criação de empregos e priorizando a reestruturação ao invés da liberalização de preços.

Suas medidas "privatizantes" foram heterodoxas não apenas porque eles desenvolveram a nova (e até aquele momento não testada) "voucher fórmula", mas porque elas resultaram em novas formas de recombinações de propriedades, com densas redes de propriedade interorganizacional. $\mathrm{Na}$ Hungria, a política oficial de desprezar os ativos interdependentes (com a ordem de privatizar estritamente empresa por empresa) resultou em novos megagrupos empresariais cujos contornos de propriedade interorganizacional diferiam dos obtidos no caso tcheco. 2 Essas redes que permitiam difundir riscos (e potencialmente assumi-los) tornaram-se mecanismos de dispersão de riscos no contexto das tentativas do governo húngaro de centralizar o gerenciamento dos passivos. $\underline{3}^{T}$ endo dado um choque de mercado não intencionado (a partir do início de 1992, com as mudanças simultâneas nas legislações bancária, de contabilidade e de falências) que levou a uma onda de falências e ao colapso financeiro iminente, o governo reverteu o curso da ação na direção estatizante, com a maciça ajuda a bancos e esquemas paternalistas de perdão de débitos, que acabaram levando o país à beira de uma falência do Estado.

Neste trabalho, avançamos da descrição para a explicação; isto é, nossa tarefa aqui é dar conta das diferenças entre as políticas nos vários casos (acrescentando a Alemanha ao conjunto de casos a comparar). $\mathrm{Na}$ busca de explicar essas diferenças, descobrimos que os casos da Europa do Leste diferem não apenas no foco e no conteúdo das políticas públicas, mas também na sua coerência, variando da relativa estabilidade de princípios e práticas até oscilações frenéticas e constantes de um curso de ação para outro. Quando o governo alemão reconheceu que a exposição impiedosa à competição do mercado tinha transformado ativos em passivos, os gestores de políticas alemães estabeleceram novas instituições de reestruturação com linhas de ação relativamente claras. ${ }^{4}$ As políticas tchecas foram ainda mais coerentes, evitando ondas periódicas de falências logo de início. Com efeito, Vaclav Klaus e seus companheiros rejeitaram a velocidade como um princípio guia das reformas, já que o ritmo de mudança, sozinho, não poderia garantir a coerência. Ao invés disso, operaram com critérios claros de modo a que a reestruturação (na direção ampla e pouco rígida de "privatização") ocorresse em moldes que protegessem ativos fixos, preservassem capital humano e mantivessem as propriedades de redes contidas nos vínculos interorganizacionais.

$\mathrm{Na}$ Hungria, ao contrário, as políticas econômicas deram guinadas bruscas de um extremo a outro. Enquanto os gestores das políticas alemãs e tchecas fizeram ajustes quando confrontados com as conseqüências de suas políticas, a cena húngara, por contraste, se asemelha mais ao padrão de regulação através de crises (tão comum nos dias do socialismo de Estado). $\frac{5}{}$ Naquele formato, cada política era implementada dogmaticamente até o momento em que a crise por ela produzida a tornasse insustentável, momento a partir do qual ela era substituída por uma política antitética cuja duração política era medida pelas tendências de crise inerentes a ela. Como a nossa discussão do caso húngaro sugere, embora os gestores das políticas sustentassem que estavam engajados em políticas de gerenciamento de crises, seria mais correto denominar o conjunto das políticas húngaras degerenciamento de crises de políticas. 


\section{Explicando as diferenças}

Como podemos dar conta das diferenças na coerência das políticas econômicas nos nossos casos? Como podemos explicar a habilidade diferenciada dos governos em produzir políticas coerentes que pudessem ser ajustadas ao invés de abandonadas?

Pode-se argumentar que o caso tcheco é uma evidência de que a consistência interna da ideologia que dá direção aos programas econômicos é um fator chave na explicação da formulação de políticas coesas e na sua efetiva implementação. Segundo esta visão, a busca firme dessas idéias seria a melhor estratégia e a coerência apareceria naturalmente onde a ideologia guiasse fielmente as políticas. Mas esta visão dificilmente corresponde à realidade tcheca - já que a prática real de Klaus foi muito marcada por seus desvios de sua ideologia ortodoxa, além da ausência de congruência entre os pronunciamentos ideológicos e os programas realmente implementados. Poder-se-ia também argumentar que a chave para uma estratégia reformista sustentável não é a adesão a princípios, mas a adoção de flexibilidade (eufemismo para uma tendência ao oportunismo). Como evidência disso alguns autores também apontam para o caso tcheco — não para a importância das idéias e da ideologia, mas para a personalidade e as habilidades políticas de seu ministro das Finanças e mais tarde primeiro-ministro. Vaclav Klaus foi um político brilhante, com uma capacidade única de descartar cinicamente sua proclamada ideologia liberal em favor de uma orientação política social-democrata disfarçada de forma sutil. Ele foi brilhante e ainda é. Mas este traço de personalidade não pode explicar as diferenças nos cursos de políticas públicas nos casos aqui analisados. Para isso, temos de atentar para as diferenças nas instituições políticas.

Dentre as diversas explicações institucionalistas presentes na literatura de análise política comparativa para a relação entre mudança política e reforma econômica, a corrente dominante sustenta que a chave para o sucesso das reformas econômicas é uma autoridade executiva forte. $\underline{6}$ A coerência das políticas seria uma função da autoridade concentrada e não limitada do executivo. Segundo esta perspectiva, nossa atenção deve ser direcionada para as relações entre as instituições estatais e outras instituições políticas: onde as configurações institucionais fragmentam, impedem, restringem, desafiam, limitam ou constrangem a autoridade do executivo, as reformas políticas falham.

Mudando a atenção da autonomia do Estado em geral para a autonomia do executivo especificamente, essa visão concebe as políticas de reforma econômica como problemas de coordenação. ${ }^{7}$ Assim, embora o problema da reforma econômica tenha sido primeiramente expresso como a necessidade de impedir que os interesses da sociedade penetrassem no Estado e subvertessem as reformas, a questão aqui é reformulada como o problema de como estruturar os interesses dos atores do Estado contra potenciais entraves institucionais (internos ao Estado) que podem dissipar a autoridade do executivo. $\underline{8}$ As configurações institucionais (restrições institucionais, governos de coalizão multipartidária, sistemas partidários fragmentados, dentre outras) que constrangem a autoridade discricionária do executivo poderiam aumentar os problemas de coordenação e, inversamente, autoridades executivas concentradas minimizariam a fricção institucional, facilitando, portanto, uma coordenação suave e desimpedida. 2 Os obstáculos institucionais que limitam a autoridade executiva confundiriam a racionalização da formulação de políticas, erodindo, conseqüentemente, a sua coerência e corroendo a sua efetiva implementação. $\underline{10}$

O foco institucional do modelo de executivo forte é congruente com nossa própria afirmação de que a questão crucial no debate não é a relação entre democracia e reforma econômica, mas se, e de que forma, os diferentestipos de democracias (no plural) diferem na sua capacidade de enfrentar as complexidades da transformação econômica. Portanto, o que consideramos como mais interessante no modelo do executivo forte é a atenção precisa dos autores às configurações institucionais diferentes e à forma como estas constrangem ou não as prerrogativas unilaterais da autoridade executiva. 
Com esta ênfase institucional em mente, podemos produzir um teste preliminar do modelo do executivo forte ordenando nossos casos de acordo com o grau de concentração/não limitação da autoridade do executivo e relacionando estes casos com a coerência de suas respectivas políticas. Os resultados indicam uma correlação sólida. O problema para a teoria do executivo não limitado, no entanto, como veremos mais adiante no texto, é que o sinal é negativo. Isso é, nossa análise dos casos do Leste Europeu sugere que as configurações institucionais que constrangem a autoridade do executivo têm maior probabilidade de produzir formulações e implementações coerentes de políticas de reforma econômica. 11 Nos casos em que a autoridade é menos constrangida, ao contrário, as políticas são menos coerentes.

Nas próximas seções, examinamos as configurações institucionais que conseguem (ou fracassam em) limitar as prerrogativas unilaterais da autoridade central executiva nos casos da Hungria, da Alemanha e da Tchecoslováquia (depois República Tcheca) e indicamos, de uma forma preliminar, como estes constrangimentos provocam políticas mais coerentes. Como veremos no caso húngaro, encontramos relativamente poucas limitações constitucionais e institucionais à concentração da autoridade executiva, assim como pequenos constrangimentos às políticas públicas por parte de atores sociais organizados. Como conseqüência, as políticas não são nem coerentes nem sustentáveis, mudando constantemente de um extremo ao outro. No caso da Tchecoslováquia (e, mais tarde, da República Tcheca), ao contrário, o espaço de manobra dos executivos centrais é relativamente mais limitado pela sociedade e por mecanismos de controle internos ao Estado e um curso moderado de política tem sido coerente e sustentável. A Alemanha, como veremos, é um caso intermediário, onde uma política relativamente extrema adotada durante o período de exceção (quando as regras institucionais do jogo estavam temporariamente anuladas pela defesa do chanceler Kohl de uma autoridade executiva concentrada na busca de sua estratégia de unificação) é mais tarde moderada, após o enraizamento das instituições federativas e corporativistas nos novos Länders da Alemanha Oriental. Seguindo uma apresentação detalhada dos casos, avançamos, em nossa seção conclusiva, de um enfoque crítico para uma análise positiva do tipo de constrangimentos benéficos ("responsabilidade política estendida") que fazem crescer a autonomia necessária para se implementar projetos de reforma econômica.

Hungria

Dos três casos examinados por nós, a autoridade executiva na Hungria foi menos limitada, constitucional ou conjunturalmente. O presidente húngaro, eleito pelo parlamento e com poderes constitucionais limitados, certamente não é forte. A autoridade executiva, ao contrário, é concentrada no gabinete do primeiro-ministro, cujos amplos poderes constitucionais são fortalecidos pelas características do "voto positivo de desconfiança". $12 \mathrm{Sob}$ este sistema, o parlamento pode registrar um voto de desconfiança somente na circunstância improvável de conseguir simultaneamente propor um novo governo. As características constitucionais que conferem ao primeiroministro húngaro o título de chanceler apenas no nome são reforçadas pela lei eleitoral, cujas regras para a tradução de votos em cadeiras no parlamento fazem com que seja possível (e até provável) que o partido mais votado que obtiver apenas um terço dos votos obtenha o status de maioria no parlamento. Esta maioria foi conseguida pelo Partido Socialista de Gyula Horn com apenas 36\% dos votos nas eleições de 1994, e foi quase conseguida pelo Fórum Democrático de Jozsef Antall nas eleições de 1990. Os resultados em ambos os casos foram governos de coalizão nos quais o partido do primeiro-ministro pôde governar com poucas concessões (e apenas consultas ocasionais) a seus parceiros minoritários. O resultado destes fatores constitucionais, conjunturais e institucionais foi que o parlamento se tornou uma sociedade abstrata de debates, e não uma instância de deliberação que pudesse assegurar acordos amplos entre posições rivais sobre políticas públicas. Neste situação, não é surpreendente que os primeiros-ministros Antall e, mais tarde, Horn tenham se empenhado em centralizar a autoridade de tomada de decisão em moldes quase personalistas. 
Essa centralização na elaboração de políticas, além disto, foi relativamente não influenciada por atores locais organizados em outras arenas institucionais. As redes interorganizacionais na Hungria, na verdade, poderiam terse engajado na reestruturação das empresas, mas apenas como reorganizações descentralizadas através da estratégia de incorporação. Estas redes, no entanto, nunca chegaram a dar origem a fortes associações patronais que articulassem posições substantivas com respeito à política econômica nacional. Neste particular, elas copiaram as deficiências do mundo do trabalho, cujos sindicatos fragmentados e fracos $\frac{13}{13}$ não conseguiram nem desafiar de forma sustentável os governos, nem se constituir em aliados confiáveis das iniciativas de políticas. Não limitado pelo Banco Central (cuja independência, sob ambos os governos, foi severamente questionada), não controlado por seus parceiros de coalizão, sem ter de responder ao parlamento, e não constrangido por compromissos assumidos de antemão com os representantes da classe empresarial e dos trabalhadores, o forte executivo húngaro teve reinado quase completamente livre - livre para fazer políticas sem levar em consideração suas conseqüências econômicas e sociais, livre para reverter seu curso sem mudar as coordenadas, livre para pular de uma crise autoinflingida para outra. A autoridade executiva concentrada expandiu o seu espaço para manobra, aumentando, conseqüentemente, os custos de seus erros e amplificando as guinadas erráticas nas políticas. Caso o Tribunal Constitucional não tivesse demonstrado sua independência mediante a oposição a aspectos da lei de restituição dos nacionalistas, bloqueando as tentativas de Antall para subordinar a televisão húngara ao gabinete do primeiroministro e contrariando alguns planos dos socialistas para desmantelar programas de bem-estar social, as guinadas erráticas nas políticas teriam sido ainda maiores(Schwartz, 1993). 14

\section{Alemanha}

No nível nacional, as relações entre as instituições estatais na Alemanha não são significativamente diferentes das presentes na Hungria - inclusive porque as instituições pós-socialistas húngaras foram em grande parte copiadas das alemãs. Da mesma forma que os poderes de ocupação no pós-guerra na Alemanha, que temendo a instabilidade de Weimar desenharam instituições com claras linhas de autoridade, $\underline{15} \mathrm{Os}$ arquitetos dos novos arranjos constitucionais húngaros optaram por governabilidade ao invés de responsabilidade política, garantindo como resultado um executivo forte. $\mathrm{Na}$ verdade, os húngaros foram ainda mais longe, introduzindo um conjunto de regras eleitorais que eram ainda mais desproporcionais que as do sistema alemão. Apesar disto, a estrutura das relações entre parlamento e governo é bastante similar nos dois casos. Como veremos, o que a Alemanha apresenta de diferente da Hungria é a sua estrutura federativa e a força de suas associações representativas.

O período de exceção

Durante os meses que se seguiram à unificação alemã, em outubro de 1990, os alemães orientais testemunharam um processo que podemos descrever literalmente como de colonização: as instituições econômicas, sociais e políticas daquele lado do muro foram substituídas por aquelas da antiga República Federativa da Alemanha (e com freqüência ocupadas por pessoal originário da Alemanha Ocidental). $\frac{16}{}$ As instituições federativas e corporativistas que caracterizaram a República Federal da Alemanha no pós-guerra, no entanto, não apareceram na Alemanha Oriental logo depois da unificação. Baseando sua campanha às eleições de 1990 na bandeira de que os mecanismos de mercado da Segunda Wirtschaftwunder (milagre econômico) restaurariam a prosperidade alemã oriental, da mesma forma como fizeram na Alemanha Ocidental durante os anos 50, o chanceler Helmut Kohl conseguiu obter impressionantes vitórias tanto no Leste como no Ocidente. Com seus amplos poderes constitucionais reforçados, conjunturalmente, pelo sucesso eleitoral que se seguiu ao seu triunfo na negociação da reunificação, o chanceler alemão "assumiu a postura de um executivo soberano não constrangido", 17 agindo como se as regras do jogo 18 não mais fossem aplicáveis naquelas circunstâncias extraordinárias. Foi no interior desta matriz política que burocracias estatais como a do Treuhandasstalt 
reformularam a Alemanha Oriental. Estas, inicialmente, não foram controladas por instituições locais ou regionais no Leste. Como se o legado patético da sociedade civil incrivelmente fraca já não fosse o bastante, os alemães orientais viram o que de pouco havia de possíveis instituições de defesa desaparecer à medida que as administrações governamentais municipais e locais foram sendo desmanteladas e os antigos sindicatos despedaçados.

Dada essa relativa ausência de instituições limitadoras do poder executivo, deveríamos esperar que, assim como na Hungria, as estruturas de tomada de decisão altamente centralizadas e fortemente concentradas na Alemanha produzissem um curso de ação radical. Em verdade, no início foi assim. Como já descrevemos anteriormente, a exposição direta à competição do mercado não deslanchou um milagre econômico mas um pesadelo econômico cujas conseqüências foram proporcionais à competição do mercado. Além disso, já que na Alemanha as origens do problema eram mais transparentes e as promessas políticas

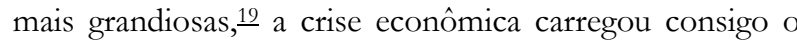
perigo de uma crise política. Os sinais disso se manifestaram logo: o assassinato do executivo chefe do Treuhand, comícios e ondas de greves no Leste, onde trabalhadores tomaram dezenas de fábricas e cidadãos ocuparam o parlamento estadual em Schwerin, capital de Mecklenberg-Vorpommern (Seibel, 1993, p. 290; McShane, 1993).

No entanto, diferentemente das guinadas da Hungria, a resposta dos administradores públicos alemães às crises econômica e política foi mais incremental e moderada. A explicação para esta diferença está na emergência de estruturas estatais e de instituições sociais e políticas que restringiram o executivo forte, constrangendo seus agentes nas burocracias estatais e moderando o curso de suas políticas. Estes arranjos institucionais eram também um legado da colonização: junto com o braço executivo do governo federal, a reunificação também trouxe à Alemanha Oriental as instituições ocidentais do federalismo (com governos autônomos nos Länders como componente crítico) e do corporativismo (com sindicatos fortes como característica crucial) (Sally e Webber, 1994). Estas instituições puderam ser rapidamente transplantadas no outono de 1990, mas foi apenas quando a crise política e as chuvas de primavera do colapso econômico iminente pairavam que elas começaram a produzir efeitos.

Ressurgido o federalismo, restauradas as deliberações,

Confrontados com níveis sem precedentes de desemprego, falências e redução do crescimento, os primeiros-ministros recém-eleitos dos novos Länders do território da antiga Alemanha Oriental não observaram passivos a oposição que ressurgia. Dentro do sistema federalista alemão, eles não eram os agentes do Bund (governo federal), mas tinham mandatos independentes dos seus respectivos eleitorados. Como políticos cujas carreiras estavam em risco, eles começaram, nos primeiros meses de 1991, a criticar fortemente as políticas de privatização do Treuhand. Como líderes dos governos locais ávidos de parte da ação administrativa no campo da reestruturação econômica (com enormes efeitos sobre suas jurisdições), demandaram o desmantelamento das agências regionais do Treuhand — responsabilidade esta que seria devolvida para os governos dos Länders(Seibel, 1993, pp. 290 e ss.).

Ao mesmo tempo, a transferência das estruturas dos sindicatos alemães ocidentais para o território orientalestava ocorrendo (Hyman,1996; Wilfried e Wisentahl, 1994). De outubro de 1989 a março de 1990, técnicos alemães ocidentais da Federação Alemã de Sindicatos (Deutscher Gewerkschaftsbund - DGB) adotaram a política de não se meter nos assuntos sindicais da Alemanha Oriental, preferindo "esperar para ver" se, e de que maneira, os sindicatos do Freier Deutscher Gewerkschaftsbund (FDGB) realizariam um processo de democratização auto-induzido, em antecipação à possível fusão em algum ponto no decorrer dos futuros dois a quatro anos. No entanto, depois da vitória eleitoral esmagadora da Allianz für Deutschland, liderada pelo CDU, na Alemanha Oriental no final de março de 1990, a estratégia de encampação de Bonn passou a ser acompanhada por uma estratégia de encampação da DGB, à medida que seus sindicatos levantavam recursos maciços para a formação de uma base para o sindicalismo no Leste 
(Fichter, 1993; Fichter e Reister, 1995). O lema virou "não esperem, se expandam", e por volta do outono de 1991 a expansão organizacional dos 16 sindicatos que compunham a DGB estava basicamente completa. No final deste ano, algo como 4,2 milhões de membros de sindicatos tinham se registrado nos novos Länders, ultrapassando os objetivos de filiação em quase 600 mil (com quase metade do número de filiados na Alemanha Ocidental, mas sobre uma base muito menor de empregados) (Fichter, 1994, p. 16). $\underline{\underline{20}}$

Foi em meio a esse esforço organizacional que, no início de 1991, os líderes de muitos desses sindicatos começaram (paralelamente aos políticos dos Länders) a desafiar as políticas do Treuhand, clamando por uma reestruturação controlada pelo Estado, ao invés de uma privatização acelerada. Enquanto as empresas da Alemanha Oriental estavam sendo forçadas a competir com as empresas de uma das maiores economias do mundo, os trabalhadores alemães orientais estavam ganhando representação de um dos mais fortes movimentos sindicais do mundo precisamente no momento em que a crise econômica se estava transformando em crise política.

Assim, por volta da primavera de 1991, a forte autoridade executiva dentro do Estado alemão não estava mais completamente sem constrangimentos, e não podia mais desenvolver a elaboração e implementação de suas políticas sem levar em conta os novos atores estatais e da sociedade, produtos institucionalizados da unificação. Os políticos federais logo entraram em intensas negociações com os governos dos Länders e com os sindicatos. O resultado foi um amplo programa de Aufschwung Ost (Renovação do Leste), consubstanciado em um conjunto de acordos firmados entre representantes do governo federal, governos dos Länders, sindicatos e associações patronais entre março e julho de 1991, $\underline{21}$ seguidos de mais deliberações sobre o Pacto de Solidariedade, para o qual, durante um período de seis meses iniciado em setembro de 1992, apenas no gabinete do chanceler, mais de 40 rodadas de negociações foram mantidas (Sally e Weber, 1994).
$\mathrm{Na}$ Alemanha, as discussões constrangeram a autoridade executiva e moderaram o seu curso de ação. Entretanto, a freqüente falta de racionalidade econômica nos subsídios públicos a firmas privadas, como vimos, sugere que as instituições alemãs avançaram apenas metade do caminho na direção de uma política coerente de reestruturação. Três fatores explicam por que a Alemanha foi na direção certa mas não reconheceu completamente o potencial para uma reestruturação guiada pelas redes. Primeiramente, ao contrário da Hungria, onde encontramos vínculos associativos na ausência de instituições deliberativas, observamos na Alemanha o inverso: instituições deliberativas na ausência de laços associativos. Em segundo lugar, em contraste com a República Tcheca, onde (como veremos) as instituições das negociações tripartites têm suas raízes na sociedade, as raízes superficiais das instituições corporativistas na Alemanha eram o produto do seu transplante para a Alemanha Oriental.

Em terceiro lugar, sob condições de unificação política, os governantes na Alemanha tinham disponível uma escolha básica na formulação das políticas: eles podiam reestruturar ativos ou redistribuir recursos. Diferentemente dos outros países pós-socialistas, a Alemanha tinha como separar a proteção à população da reestruturação das firmas. Esta redistribuição tomou diversas formas. Em 1994, mediante os mais invisíveis canais presentes nos sistemas de proteção social (saúde, pensão e provisões para o desemprego, por exemplo), as transferências de pagamentos respondiam por $40 \%$ da renda familiar disponível na Alemanha Oriental (Seibel, s/d, p. 14). Os recursos também foram distribuídos através do orçamento público, de certa forma mais visível, na medida em que os governos dos Länders foram pacificados parcialmente pela sua integração consolidada ao sistema geral de redistribuição de impostos. Assim, os problemas políticos dos novos governos dos Länders e aqueles das lideranças sindicais na Alemanha do Leste eram, ao menos em parte, solucionáveis sem esforços ativos de reestruturação. Além disto, a redistribuição encontrou aliados não apenas no Leste mas também no Ocidente, já que tanto os sindicatos ocidentais como os empregadores ocidentais compartilhavam do interesse 
comum em impedir a competição do Leste, tanto em produtos como no mercado de trabalho. Enfrentando a opção entre a reestruturação e a redistribuição, a escolha da política alemã foi fazer os dois. Esta escolha não estava disponível na República Tcheca, onde tanto os elementos deliberativos como os associativos eram robustos.

Repuiblica Theca

Como na Hungria, o presidente da República Tcheca é eleito pelo parlamento. Embora o ocupante atual da Presidência, Vaclav Havel, tenha considerável autoridade moral, o posto é em grande parte cerimonial e tem poderes constitucionais limitados. Mas, ao contrário da Hungria, onde o primeiro-ministro é quase um chanceler, a autonomia da autoridade executiva no caso tcheco é mais constrangida pela Constituição, pelas instituições e pela conjuntura.

Também diferentemente da Hungria, onde, como vimos, a formação dos partidos políticos precedeu a dissolução do antigo regime, e onde a competição eleitoral foi ela mesma a forma peculiar húngara de sair do socialismo de Estado, na Tchecoslováquia, a "Revolução de Veludo" de novembro de 1989 levou movimentos como o Fórum Cívico (nas terras tchecas) e a Ação Pública contra a Violência (na Eslováquia), e não partidos, a assumirem o governo depois das eleições fundadoras de junho de 1990. Estes amplos movimentos sociais e políticos se dividiram em partidos durante o ano de 1991. Em 1992, após as eleições parlamentares de junho, os líderes dos partidos tchecos e eslovacos mais importantes (Vaclav Klaus e Vladimir Meciar, respectivamente) negociaram o "Divórcio de Veludo", que culminou com a independência das Repúblicas Tcheca e Eslovaca em 1º de janeiro de 1993. O desenrolar destes acontecimentos deve ser relacionado diretamente ao processo de produção das políticas econômicas: na Tchecoslováquia, a escolha de caminhos para as políticas públicas no campo econômico (dizendo respeito a privatização, falências, emprego, salários e assemelhados) ocorreu precisamente durante o período em que a autoridade executiva estava em mãos de políticos e administradores envolvidos com a formação dos partidos e a separação das duas repúblicas.

Constrangimentos institucionais, políticas restringidas

Assim, em contraste com os primeiros-ministros húngaros Antall e Horn, que puderam governar o país liderando seus partidos majoritários (ou quase majoritários), Vaclav Klaus assumiu o cargo de ministro das Finanças como um político sem partido. Mas ele não sofreu longamente com esta deficiência política: sem muito pudor para com suas delicadezas anteriores, que haviam permitido que as diferenças políticas não fossem discutidas no interior da comunidade dissidente, ele declarou a seus colegas do Fórum Cívico que os dias de diletantismo haviam terminado. A partir de então, ele teria um partido político, um partido declaradamente de direita, e que seria dele. Mas, mesmo quando Klaus, o político, estava delimitando em linhas pesadamente ideológicas o caminho que levaria à divisão do Fórum Cívico e à criação do seu Partido Democrático Cívico (ODS), no final de fevereiro de 1991, Klaus, o ministro das Finanças, já estava praticando a política do pragmatismo.

No caso tcheco, o executivo forte foi limitado em primeiro lugar porque o parlamento não estava sob o seu comando. Se os neoliberais podiam garantir apoio para a estabilização mediante políticas monetárias restritivas, não havia garantia de que a maioria precária no parlamento conseguiria fazer com que fosse aprovado o programa de privatização extremamente ambicioso que aparecia no topo de suas prioridades. $\underline{22}$ Em segundo lugar, o executivo forte foi ainda mais constrangido pelo fato de o governo também não estar sob o seu comando. No decorrer desse mesmo período formativo, as políticas social e trabalhista estavam, em grande parte, nas mãos da ala social-democrata do Fórum Cívico (Rutland, 1994; Orenstein, 1994, p. 14). Se estivesse completamente desimpedido, não era inconcebível que Klaus tivesse deliberadamente desprezado as propriedades dos passivos e ativos advindos da sua estruturação em redes; mas a necessidade de acomodação com o parlamento e outros ministros suavizaram suas políticas, fazendo-o levar em conta 
questões sociais mais amplas. Como conseqüência, o programa de transformação das propriedades de Klaus veio ao mundo como gêmeos — seu plano principal foi acompanhado de uma política cautelosa que incluía linhas antifalência, políticas para o mercado de trabalho e medidas de bem-estar social. Conjuntamente, estas políticas gêmeas (mas não univitelinas) compuseram uma estratégia de reestruturação econômica mais coerente. $\underline{23}$

É possível supor que as políticas mudariam com a vitória eleitoral de Klaus e sua ascensão ao cargo de primeiroministro, após as eleições de junho de 1992. Com seu próprio partido vitorioso e disciplinado e como primeiroministro, responsável pela escolha dos ministros de seu gabinete, Klaus conseguiu superar as condições iniciais que o restringiam em adotar um plano de ação ainda mais amplo. No entanto, os fundamentos da linha de políticas que haviam sido colocadas em prática durante 1991 continuaram presentes ao longo dos anos de 1992 e 1993 porque Klaus continuou restringido por um conjunto de fatores constitucionais e conjunturais.

Como resultado das eleições parlamentares de 1992, o Partido Democrático Cívico de Klaus na verdade tornouse o maior partido em cada uma das câmaras onde tinha lugares. Apesar disto, não era um gigante parlamentar. Ao contrário dos Socialistas Húngaros, que podiam ganhar $34 \%$ dos votos nas listas partidárias e assim mesmo obter (por meio de uma combinação de regras eleitorais desproporcionais e ganhando um certo número de distritos de apenas um membro) 53\% dos assentos no parlamento unicameral, o espaço para manobra parlamentar do ODS estava constrangido por regras eleitorais diferentes e pelos limites constitucionais da estrutura federativa tchecoslovaca. Para o parlamento da República, ganhar $30 \%$ dos votos deu ao ODS 38\% dos assentos (76 de 200) na Assembléia Nacional Tcheca. Mas para as duas casas da Assembléia Nacional o partido obteve apenas 32\% (48 de 150) dos assentos na Assembléia do Povo e somente 25\% (37 de 150) dos delegados para a Assembléia das Nações.

A estrutura multicameral do federalismo parlamentarista tchecoslovaco, devemos ressaltar, tinha uma característica especialmente contrária à formação de maiorias. Embora a Eslováquia respondesse por aproximadamente um terço da população da Tchecoslováquia, os assentos na câmara alta da Assembléia Federal (a Assembléia das Nações) não obedeciam à mesma proporção. Ao invés, metade dos delegados eram eleitos por cidadãos da Eslováquia e a outra metade por cidadãos das terras tchecas. Como conseqüência, apesar de seu caráter minoritário na câmara baixa federal (a Assembléia do Povo), os partidos eslovacos, que eram bem menos entusiastas das reformas econômicas rápidas, podiam usar a câmara alta para bloquear efetivamente qualquer legislação federal sobre transformações econômicas.

Assim, ao longo de todo o período no qual estava formulando e iniciando a implementação de sua estratégia econômica, Klaus (tanto como ministro das Finanças como no cargo de primeiro-ministro) tinha de conseguir obter amplos acordos políticos para garantir a aprovação legislativa de seus programas. Antes do "Divórcio de Veludo", era impossível separar a questão eslovaca das questões de política econômica. Os políticos eslovacos, que foram provavelmente os primeiros a sentir as pressões do desemprego crescente, por exemplo, eram mais receptivos a apoiar uma reestruturação econômica se associada a políticas de apoio ao mercado de trabalho. Da mesma forma, políticas antifalências foram concebidas, não em pequena medida, como um esforço para evitar a previsível situação explosiva de pedidos de falência contra empresas eslovacas por parte de bancos tchecos (Brom e Orenstein, 1994, p. 894). Assim como na Alemanha, também na Tchecoslováquia as estruturas federativas impuseram limites constitucionais à autoridade executiva e moderaram as políticas mediante o estabelecimento de uma ampla variedade de mecanismos de responsabilidade política entre instituições e através da promoção de fóruns para discussões e deliberações mais amplas. $\underline{24}$

No período que se seguiu à separação legal entre as Repúblicas Tcheca e Eslovaca, em 1 de janeiro de 1993, poderíamos esperar novamente que Klaus, agora livre do problema eslovaco e de seus constrangimentos federativos, se sentiria livre para finalmente "tirar suas luvas" e trazer a 
prática das políticas ao encontro de seus alinhamentos ideológicos. Entretanto, o período posterior à independência não assistiu a guinadas dramáticas no curso das políticas adotadas anteriormente. Para sermos precisos, a legislação de falências bancárias foi retirada de seus dois anos de congelamento profundo mas sua implementação permaneceu tremendamente seletiva e altamente cuidadosa..$\underline{25}$ Com relação às políticas sociais, os subsídios à criação de empregos não foram desmantelados (Orenstein, 1994, p. 12), e ao invés da liberalização de preços, os tchecos continuaram a gozar de amplos subsídios para habitação e serviços públicos. $\underline{26}$ Se ocorreram realinhamentos, como vimos nos "dez mandamentos revisados" apresentados anteriormente, foram no sentido de compatibilizar os pronunciamentos ideológicos à prática. Até o momento, como se pode notar nos pronunciamentos públicos de Klaus, a fórmula padrão permanece: os termos "visão" e "pragmatismo" são tão inseparáveis que, se um aparece, o segundo também surgirá, com freqüência antes do final da frase. $\underline{27}$

Esta institucionalização dos caminhos seguidos pelas políticas foi reforçada por um conjunto final de constrangimentos (menos institucionais que conjunturais) sobre o executivo forte no período pós-independência. Se anteriormente Klaus tinha de cuidar das políticas de reforma econômica em três câmaras parlamentares, depois da independência ele passou a enfrentar apenas um corpo legislativo - o Conselho Nacional Tcheco. No entanto, a maioria parlamentar de seu governo de coalizão multipartidária não era muito significativa. A aliança eleitoral por ele promovida entre ODS e KDS lhe rendeu 76 cadeiras no parlamento tcheco; a aliança Partido do Povo-União Cristã Democrática detinha 15 cadeiras e a Aliança Democrática Cívica, 14 representantes. Juntos, os partidos da coalizão governamental tinham a pequena maioria de 52\%.르 Com apenas 105 de 200 delegados, Klaus não estava em posição de ignorar os seus parceiros de coalizão: se apenas seis representantes de seus parceiros menores mudassem de lado ele ficaria em minoria e perderia o seu governo. Como conseqüência, o parlamento tcheco manteve-se como um genuíno corpo deliberativo, e os ministérios ocupados pelos parceiros de coalizão de Klaus gozaram de autonomia considerável. Quando consideramos em nossa equação um Banco Central verdadeiramente independente, chegamos à conclusão de que, no caso tcheco, o parlamento, o Ministério das Finanças, o Ministério da Indústria e Comércio e o Banco Central coexistiram como centros de produção de políticas relativamente autônomos.

Novamente, a comparação com a Hungria é esclarecedora. Com o MDF ocupando 42,5\% do parlamento e seu governo de coalizão compondo uma maioria parlamentar de $60 \%, \underline{29}$ o primeiro-ministro Jozsef Antall pôde centralizar autoridade prestando muito menos atenção às posições dos partidos minoritários de sua coalizão governamental, já que podia suportar (e realmente enfrentou) uma considerável queda no apoio de seus delegados parlamentares. De forma similar, a centralização de Gyula Horn baseou-se na maioria absoluta de 53\% de seu Partido Socialista e na maioria qualificada (dois terços) que alcançava se fossem considerados também os seus companheiros de coalizão, os Democratas Livres. O contraste com o caso tcheco é instrutivo pois oeleitorado húngaro não era maior entusiasta do MDF em 1990 ou dos Socialistas em 1994 que o eleitorado tcheco era do Partido da União Democrática de Klaus em

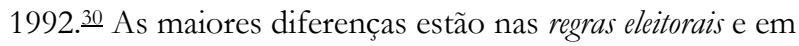
suas conseqüências institucionais. Na Hungria, as regras eleitorais, objetivando alcançar maior governabilidade, premiavam o partido que obtivesse o maior número de votos, ao passo que, no caso tcheco, as regras, tentando favorecer maior "representatividade", aumentavam a possibilidade de que mais partidos tivessem voz no governo. Enquanto o primeiro exibe um desvio em favor do partido com uma pluralidade simples, o último favorece umpluralismo mais complexo e diverso.

Governo e trabalho: restrições mútuas e consenso construído através do conflito

Uma característica similar de inclusividade marca a relação entre o governo tcheco e os sindicatos. Os sindicatos tchecos obviamente não eram tão poderosos quanto a 
DGB alemã, nem suas instituições corporativistas tão decisivas quanto no caso alemão. Mas a força dos sindicatos tchecos e o destaque da intermedição corporativista não estavam ausentes, especialmente se comparadas com as duras experiências das outras sociedades do Leste Europeu pós-socialista: a Confederação Tcheca de Sindicatos (e mais tarde as Câmaras de Sindicatos Tcheca e Moldava) tem sido a única federação unitária de sindicatos da região, e a Tchecoslováquia pós-socialista o primeiro país da região a estabelecer negociações tripartites, sendo que estas instituições mantiveram sua vitalidade no período pósindependência. Do início do processo até hoje, a relação entre governo e trabalho organizado tem mostrado um padrão consistente de restrição mútua. Em face da persistente defesa dos direitos básicos do trabalho organizado feita pelos sindicatos, o governo evitou ataques frontais contra eles. Por outro lado, diante da insistência do governo em não comprometer os pontos básicos de seu programa de reforma econômica, os sindicatos evitaram mobilizações contra este último. Mesmo com ameaças e contra-ameaças, o resultado foi a produção de uma harmonia social através dos conflitos, na medida em que negociações repetidamente reproduziram a estratégia de crescimento baseada em três pilares: salários baixos, desemprego baixo e sólidos direitos sindicais.

A pré-história da política trabalhista da República Tcheca pós-socialista teve uma data relevante, o dia 27 de novembro de 1989. Naquele dia, movimentos sociais lideraram uma greve geral que levou à queda final do regime comunista. Única greve do gênero nas "revoluções de 1989", esta ação coletiva sobrevive na memória coletiva: os sindicatos de hoje devem sua legitimidade àquela greve bem-sucedida.

Nos primeiros meses de 1990, novos líderes trabalhistas, sob a liderança da Associação Nacional de Comitês de Greve, rapidamente tomaram os antigos sindicatos a partir de baixo e ganharam o reconhecimento governamental de seu direito de dividir entre os novos sindicatos as propriedades (prédios, clubes, colônias de férias etc.) dos antigos conselhos regionais de trabalhadores. No Congresso Geral dos Sindicatos, em 3 de março de 1990, os delegados dos 50 novos sindicatos formalmente desmantelaram os 17 sindicatos industriais do antigo Movimento de Sindicatos Revolucionários e estabeleceram a Confederação Tchecoslovaca de Sindicatos. A partir deste momento, a gerência efetiva da atividade sindical passou a ser coordenada separadamente pelas Câmaras Sindicais formadas nas Repúblicas Tcheca e Eslovaca (Myant, 1994, p. 61; Rychetnik, 1995, p. 242).

Com tempo suficiente apenas para se mudarem para seus novos escritórios, os novos sindicatos rapidamente aprenderam, durante o verão de 1990, que o ministro das Finanças Vaclav Klaus não pretendia lançar sua carreira na política pós-socialista como um amigo dileto do trabalho organizado. Embora o novo governo federal estabelecido após as primeiras eleições pós-comunistas, em junho de 1990, tenha proclamado em seu programa a "conveniência de consolidar sindicatos fortes" como "parceiros sociais" para "negociações sobre condições sociais e de trabalho" (Rychetnik, 1995, p. 244), quase ao mesmo tempo enviou para o novo parlamento um projeto de lei sobre greves. Notando que o projeto se assemelhava a um outro, que a Assembléia Federal Comunista havia analisado em 1989 mas não tinha tido tempo de ratificar, os sindicatos condenaram o esboço de legislação, considerando-a uma "lei antigreves". Com a greve bem-sucedida que havia derrubado o governo ainda fresca em suas memórias, os neoliberais retiraram o projeto.

Escaramuças similares continuaram durante todo o ano de 1990, quando o movimento sindical montou uma campanha ativa em torno do Código do Trabalho (com o Sindicato dos Metalúrgicos agregando 600 mil assinaturas em quatro dias em uma petição de protesto contra o primeiro projeto do novo código) e ameaçou entrar em greve por estar insatisfeito com as propostas da Lei de Negociações Coletivas. $\underline{31}$ Mas, enquanto estes movimentos ocorriam em público, os sindicatos estavam profundamente envolvidos em esboçar a legislação trabalhista, e, com a participação ativa da Organização Internacional do Trabalho, os resultados foram um sistema de leis trabalhistas favorável, em termos gerais, aos sindicatos. Com a Lei de Salários de 1991, a Lei Trabalhista 
emendada e a Lei de Negociações Coletivas de 1991, os sindicatos tchecos asseguraram direitos organizacionais importantes: os empregadores, por exemplo, não podem contratar trabalhadores para repor grevistas durante uma greve; os direitos de negociação e de greve dos sindicatos são protegidos de acordo com as normas da OIT; os trabalhadores tchecos gozam de proteção relativamente forte contra dispensa do trabalho e os empregados dispensados são elegíveis para indenizações bastante generosas (Orenstein, 1994, pp. 6 e 8; Rutland, 1994, pp.1314; Rychetnik, 1995, pp. 242-244). $\underline{32}$

Os sindicatos da Tchecoslováquia (e depois da República Tcheca), no entanto, não estavam apenas defendendo e institucionalizando seus direitos e interesses organizados; junto com o governo, eles estavam estabelecendo o quadro institucional para a intermediação de interesses. Em 10 de outubro de 1990, o Conselho de Coordenação, representando a confederação de associações de empresários, a Confederação Tcheca do Trabalho e o governo concordaram em estabelecer o Conselho para Acordo Social e Econômico. O acerto requeria que todas as legislações importantes que afetassem empregados e sindicatos (assim como outras questões de política social) fossem discutidas previamente no Conselho antes de serem enviadas ao parlamento. Além destas deliberações sobre políticas, o Conselho também teria a função de estabelecer a agenda, já que era responsável pela produção de um acordo geral sobre as políticas de emprego e salários para o ano seguinte.

O Conselho para Acordo Social e Econômico, portanto, constituiu um fórum para as complexas negociações que produziram a Lei Trabalhista e a Lei de Negociações Coletivas. De forma similar, foi mediante as deliberações tripartites do Conselho que o trabalho organizado conseguiu impedir a tentativa do governo, no final de 1993, de banir os sindicatos do serviço público e as negociações coletivas na administração estatal. As deliberações tripartites nem sempre ocorreram de maneira suave (os sindicatos se retiraram das negociações em julho de 1991, por exemplo, em protesto à recusa do governo de aumentar o salário mínimo no nível definido no Acordo Geral)
(Rychetnik, 1995, p. 243) $\underline{33}$ e em alguns momentos foram ácidas (como quando Klaus denunciou as demonstrações sindicais pacíficas da Praça Central de Praga em 23 de março de 1994, comparando-as às demonstrações de 1948, nas quais Klement Gottwald proclamou o golpe comunista) (Orenstein, 1994, p. 20), mas nestes e em casos similares os dois lados voltaram à mesa de negociações e resolveram suas diferenças. Omodus operandi no processo conflituoso de produção do consenso parece ter sido manobras de baixa intensidade para ganhar vantagens táticas e limitadas, ao invés de ataques frontais para desarmar estrategicamente o oponente.

Junto com seu trabalho de institucionalizar os direitos sindicais, o Conselho tripartite foi também eficaz em assegurar a estratégia de baixos salários e baixo desemprego típica da economia tcheca no período pós-socialista. Os custos totais dos salários são consideravelmente mais baixos na República Tcheca que nos vizinhos Hungria e Polônia. Ao mesmo tempo, no entanto, o desemprego na República Tcheca é não apenas mais baixo que nas outras economias pós-socialistas, mas é próximo a 3\%, o mais baixo da Europa. O baixo nível do desemprego tcheco é em parte explicado pelo fato de que parcela significativa do choque do colapso dos mercados de exportação para as antigas economias socialistas foi suportado pela Eslováquia (onde o desemprego registrado alcançava quase 15\% no final de 1994); de forma similar, a habilidade do governo tcheco para explorar o grande potencial do país para o turismo (que cresceu quase 50\% entre 1992 e 1994) foi um promotor de prosperidade, promovendo novos empregos em serviços, construção de hotéis, especialmente em Praga. $\underline{34}$ Mas eventos pontuais são apenas parte da explicação. Na verdade, baixos salários e baixo desemprego têm sido parte de uma estratégia explícita de política.

Os sindicatos tchecoslovacos (e posteriormente tchecos) têm feito do pleno emprego o lema central de seus programas desde 1991. Para alcançar este objetivo, eles têm aceitado baixos salários como um custo da reestruturação econômica. Estes custos são aceitáveis, primeiro, porque os sindicatos sabem que baixos salários podem contribuir para baixo desemprego. Como Rutland (1994, p. 10) observa, 
"os custos do trabalho são tão baixos que as empresas podem manter os trabalhadores na folha de pagamentos e empreendedores privados acham barato contratar mais". Em segundo lugar, o trabalho organizado tem aderido aos acordos gerais de salários no Conselho tripartite porque, em retribuição à sua restrição nos salários, o governo tem mantido seus compromissos de se mover com cautela na área de falências (restringindo conseqüentemente as dispensas), assim como de desenvolver políticas ativas no mercado de trabalho. $\mathrm{O}$ aspecto preservador de postos de trabalho do primeiro é difícil de medir, mas Orenstein (1994, p.12) ressalta que as políticas ativas no mercado de trabalho resultam em ganhos significativos: "Durante 199293, o número de pessoas empregadas através de diversos programas de emprego variaram entre 100.000 a 140.000 , alcançando em torno de $2 \%$ do emprego total. O governo tcheco gastou 1,7 bilhão de coroas (58 milhões de dólares) em políticas de ativação do mercado de trabalho em 1992".

Assim, deliberações institucionais tornaram possível para os sindicatos mudar seus horizontes temporais, como, por exemplo, quando Vladimir Petrus, líder da Câmara Tcheca de Sindicatos entre 1992 e 1994, definiu explicitamente a estratégia de reforma do governo como "a chave para a prosperidade que poderia tornar realizáveis os objetivos de longo prazo dos sindicatos" (Myant, 1994, p. 6; ênfase nossa). $\frac{35}{}$ Ao mesmo tempo que as estruturas tripartites moderaram as demandas dos sindicatos, elas moderaram as políticas do governo, assim como seus horizontes temporais. Apesar de sua antipatia inicial aos sindicatos, Klaus acabou aprendendo, através do processo de negociação, que o trabalho podia ser um aliado, e deliberações tripartites, um instrumento para construir o consenso sobre as políticas de reestruturação econômica. $\frac{36}{6}$

Aqui, novamente, a comparação com a Hungria é ilustrativa. $\frac{37}{}$ Naquele país, a estratégia do governo de Antall de dividir e conquistar o movimento sindical foi bemsucedida, conseguiu excluir os sindicatos da formulação de políticas e, conseqüentemente, os impediu de exercer uma influência moderadora na política e sobre os seus próprios membros. Os resultados foram danosos tanto para o trabalho organizado como para a economia nacional, com grandes elevações e quedas nos valores reais dos salários e maior imprevisibilidade no comportamento dos empresários, dos trabalhadores e do governo durante o período (Bruszt, s/d). A maior inclusão do trabalho organizado na política tcheca é ainda mais impressionante quando comparada com a política dos socialistas húngaros em 1994-95. Tendo obtido sua vitória eleitoral com a ajuda significativa dos sindicatos socialistas, seria de se esperar que Gyula Horn e sua equipe fossem ativar as instituições tripartites existentes e alterar as características abertamente antitrabalho da legislação aprovada por seus antecessores. Ao contrário, tratando-as como meros paliativos a serem usados depois do acontecimento dos fatos, eles desestruturaram as instituições de deliberação social. Até o presente momento, os socialistas não introduziram nenhuma legislação para modificar a lei trabalhista húngara e suas cláusulas sobre greves e negociações coletivas. .38 Mesmo sem um partido político aliado, os sindicatos tchecos foram suficientemente fortes para garantir um conjunto de direitos institucionais e defender os interesses de suas organizações. Com suas erupções cáusticas para comprovar que não são as atitudes, mas as instituições, que fazem a moderação, Vaclav Klaus estava, no entanto, suficientemente limitado para aprender que ele tinha mais a ganhar fazendo uma oferta a seus oponentes do que tentando desarmá-los. Não foram os políticos trabalhistas, mas o chanceler democrata-cristão Kohl e o primeiro-ministro neoliberal Klaus que utilizaram as instituições de deliberação tripartites e, fazendo isto, foram moderados por elas.

Nosso exame dos três casos da Europa Central nos rendeu uma descoberta em flagrante contradição com o centro nodal do modelo do executivo não limitado, já que, como vimos, onde as estruturas institucionais colocam fortes limites à autoridade do executivo as políticas são mais coerentes. Executivos relativamente não constrangidos (na Hungria e na Alemanha durante o momento seguinte à unificação) produziram políticas cujas conseqüências não intencionadas levaram a crises e provocaram a reversão dessas políticas. Executivos relativamente constrangidos (na Tchecoslováquia de 1990 
a 1992; na República Tcheca depois da separação e na Alemanha depois que as instituições do federalismo e do corporativismo começaram a produzir efeitos) com maior probabilidade produziram políticas coerentes que puderam ser ajustadas ao invés de abandonadas. Nossas descobertas de uma correlação negativa entre autoridade executiva concentrada e coerência nas políticas nos levam a rejeitar o modelo do executivo não limitado. Na seção que se segue, um quadro teórico alternativo para a compreensão das fontes institucionais de políticas sustentáveis de transformação econômica é elaborado a partir de nossos estudos de caso.

\section{Responsabilidade política estendida}

Quais são as implicações destas descobertas para a relação entre estruturas políticas e políticas de reforma? Em particular, qual é a relação entre responsabilidade pública e autoridade para executar políticas de reforma? O modelo do executivo não limitado, é claro, opera a partir da premissa, amplamente aceita na teoria política,,$\underline{39}$ de uma troca de soma zero entre autoridade e responsabilidade política: quanto menos responsabilizado politicamente, mais o centro reformador é capaz de representar a vontade coletiva; quanto menos conectado, mais capaz de coordenar o seu programa. Sem o constrangimento dos laços que amarram, o executivo não constrangido pode se comportar de forma responsável porque tem total autonomia para levar a cabo as difíceis tarefas que as situações demandam.

Em contraste, nossa análise sugere um fenômeno organizacional paradoxal apenas à primeira vista, já que a capacidade executiva, entendida aqui como a capacidade de formular e implementar programas de reforma, pode ser aumentada via limitações nas prerrogativas unilaterais da autoridade executiva. Executivos que são forçados à responsabilidade política por outras instituições estatais e colocados em cheque por atores organizados da sociedade não são necessariamente executivos fracos. Na verdade, suas políticas podem ser mais efetivas. Segundo esta visão, a coerência de políticas para reformas econômicas sustentáveis é um resultado da responsabilidade política estendida.

Por responsabilidade política estendida nos referimos à imbricação dos centros de tomada de decisões em redes de instituições políticas autônomas que limitam a arbitraridade dos governantes no poder. Responsabilidade política estendida difere, primeiro, da responsabilidade "vertical" das eleições periódicas, pois ela estende a responsabilidade "borizontalmente" em um conjunto de relações através das quais os executivos são forçados à responsabilidade política por outras instituições estatais. Expondo as políticas a maior vigilância, a responsabilidade política estendida reduz a possibilidade de os executivos cometerem enormes erros de cálculo em políticas extremas e sem consideração para com outros atores. $\stackrel{40}{ }$ A responsabilidade política estendida se diferencia, em segundo lugar, da simples responsabilidade eleitoral porque, ao contrário do caráter episódico desta última, ela é estendida no tempo. Estendendo a responsabilidade como um processo contínuo, em curso, elareduz as possibilidades de que o executivo possa apelar para a "crise" como tentativa de legitimar a expansão de sua autoridade eleitoral "delegada".41 Como nossas análises dos casos tcheco e alemão sugerem, longe de impedir a coordenação estatal, esta deliberação estendida na rede de instituições autônomas que acompanham a formulação e implementação das políticas na verdade aumenta as possibilidades de coordenação a priori entre elas.

Nestas primeiras duas dimensões (vertical e temporal), a responsabilidade política estendida carrega óbvias semelhanças com o conceito de "responsabilidade horizontal" empregado por Guillermo O'Donnell em sua crítica das recentemente estabelecidas, mas pouco consolidadas, democracias da América Latina. Rejeitando o círculo vicioso de frenesi decisório que erode a confiança na mesma medida em que pede cada vez mais autoridade para um executivo central curiosamente onipotente e impotente ao mesmo tempo, 42 O'Donnell defende a responsabilidade horizontal entre instituições estatais. Nossa noção de responsabilidade política estendida engloba esta 
característica do modelo de O'Donnell mas avança para estender a responsabilidade em escopo, ao incluir não apenas instituições internas ao Estado, mas também outras instituições políticas, em particular os outros agentes organizados da sociedade, em redes de responsabilidade. $\underline{43}$

Esta visão é obviamente implausível do ponto de vista do modelo do executivo não limitado. Dentro daquela lógica, os especialistas que têm autoridade delegada pelas autoridades executivas, que por sua vez receberam a delegação popular, já têm a inteligência necessária no sentido duplo do termo: eles dominam a informação requerida e são portadores da inteligência iluminada necessária para saber o que precisa ser feito. Segundo esta visão, enquanto os constrangimentos horizontais confundiriam a política com problemas de coordenação no interior do Estado, a inclusão de interesses da sociedade representaria, sem dúvida, uma poluição na formulação e implementação de políticas. A responsabilidade política estendida somente diluiria a autoridade desses especialistas e erodiria a coerência das políticas. Nossa análise dos casos tcheco e alemão, entretanto, sugere o oposto: embora imperfeita, a inclusão política relativa de interesses subordinados da sociedade fortaleceu a autoridade executiva e aumentou a coerência das políticas. A responsabilidade estendida a corpos regionais nos quais o trabalho tenha uma representação de destaque, assim como a extensão de deliberações a instituições tripartites de negócios, trabalho e Estado, não resultaram em compromissos danosos. Ao contrário, representaram canais institucionais de destaque para manter as políticas "no curso"..44 Trazer a sociedade de volta à política no momento da formulação da política significou que os administradores públicos não confrontraram a sociedade apenas no momento da implementação das políticas. Ao contrário, as discussões aumentaram a compreensão dos formuladores das decisões, provendo informações críticas que os ajudaram a antecipar conseqüências econômicas, políticas e sociais futuras de suas ações. A responsabilidade política estendida, portanto, estendeu o horizonte temporal dos atores estatais chave, corrigindo erros de cálculo de antemão e os encorajando a pensar vários passos à frente nos jogos estratégicos da política de reformas. Como as deliberações os forçaram a ser mais responsáveis ex ante, as linhas de política pública resultantes já estavam delineadas de forma coesa e coerente, o que facilitou respostas rápidas e adaptações responsáveis com a alteração das circunstâncias. As deliberações estendidas não tornaram as políticas mais "fracas": elas amenizaram as políticas, tornando-as mais duráveis por serem mais elásticas. A responsabilidade política estendida não comprometeu os políticos: tornou suas visões mais pragmáticas.

\section{Autoridade e responsabilidade politica}

Como interesses heterogêneos da sociedade podem ser trazidos para dentro do Estado sem comprometer programas ambiciosos de reforma econômica? O perigo de trazer estes interesses diretamente para uma burocracia amplamente inserida (embedded), embora desagregada, está em que as políticas de reforma podem acabar desagregadas. $\frac{45}{}$ De forma semelhante à dinâmica de corrosão das políticas sob o socialismo de Estado, a coerência das políticas seria dissipada em uma multiplicidade de pontos de acordo burocráticos, tão fraturados e fragmentados que a administração estatal escaparia à responsabilidade, como conseqüência.

Como nossa explicação do conceito de responsabilidade política estendida tem mostrado até o momento, a resposta a este problema está em estender nossa análise do campo da burocracia estatal e do domínio no interior das instituições estatais para examinar as propriedades do campo da política. Em uma primeira e grosseira aproximação de seus contornos, podemos dizer que como e onde a responsabilidade funciona de forma efetiva, as respostas que saem do campo da política são princípios generalizados e linhas gerais, sendo sua dinâmica interna delimitada por lutas sobre formas específicas de "crédito". Seus atores centrais são políticos, disputando reivindicações de credibilidade e interagindo com instituições estatais e com outras organizações que mediam interesses da sociedade (Bourdieu, 1991). $\underline{46}$ 
O que os políticos de reformas fazem? Mais especificamente, como eles se engajam nas políticas de transformação que contribuem para a responsabilidade política estendida? Para examinar o trabalho dos políticos, exploramos a noção de prestar contas de $\Perp$ (Stark, 1996). Rica etimologicamente, a expressão tem ao mesmo tempo o sentido de contabilidade e narrativa. Ambas as dimensões partem de julgamentos, e cada uma pressupõe a outra: os contadores preparam histórias escritas de acordo com fórmulas estabelecidas, e nas descrições de um bom contador de histórias nós sabemos o que conta. A política é uma forma especial de contabilidade política. Os políticos "abrem contas" e "fazem contabilidade". Eles abrem contas quando pedem para o eleitorado: "ponham crédito na minha conta". Eles dizem: "me dêem crédito, invistam em mim, me autorizem a agir no seu lugar". Mas os políticos que simplesmente levam em conta uma miríade de interesses serão penalizados no quadro da competição política. Para serem bem-sucedidos na dinâmica da competição partidária, os partidos devem ganhar apoio de grupos sociais com interesses e racionalidades amplamente diferentes e às vezes até mesmo conflitantes. Estratégias vencedoras subordinam estes interesses particulares em narrativas agregadas e totalizantes conhecidas como programas políticos.

Preparando esses programas como formas específicas de contabilidade/narrativa, os políticos exploram o caráter duplamente associativo dos recursos - como vínculos entre grupos e como ligações no interior de redes decategorias ${ }^{47}$ que se constituem em princípios legitimadores. O trabalho de forjar e manter um programa político sempre envolve reagrupar recursos políticos - rearranjar os elos sociais entre grupos e fazer novas "associações" entre as categorias políticas e cognitivas através das quais a sociedade se representa. Fazendo estas associações, eles não apenas representam interesses (simplesmente marcando presença no campo político já dado e com posições fixas), mas principalmente os reconfiguram mediante o estabelecimento de novas conexões entre eles, às vezes aparentemente contraditórias. Colocando de forma diferente, as narrativas de um programa político não apenas representam interesses: elas reconstroem identidades. Programas políticos são portanto duplamente associativos: reivindicando representar, falar em nome de grupos sociais específicos (por exemplo: "Nós somos o partido do trabalho $e$ dos pequenos empresários"), eles tentam criar alianças; escolhendo um curso de ação particular, eles tentam modificar os "vínculos de associação", representando as maneiras da sociedade funcionar e ser transformada (por exemplo: "Demandas salariais moderadas podem aumentar a rentabilidade e a capacidade de exportar, conseqüentemente aumentando os níveis de investimento e assegurando retornos ao governo, permitindo a melhoria da infra-estrutura e o investimento em capital humano, levando à estabilização do emprego e ao aumento dos salários").

Assim, os partidos políticos competem em "sistemas de representação" não só em suas pretensões de falar por delegação de grupos sociais específicos, mas nos seus esforços deliberados de alterar os contornos dos mapas cognitivos nos quais a sociedade é "representada". Programas políticos bem-sucedidos não mantêm os vínculos associativos existentes, mas tentam deliberadamente moldar novas associações que quebrem as fronteiras dos agrupamentos sociais previamente estabelecidos. A política representativa é uma luta sobre as divisões e visõesdo mundo social. Na política de reforma, partidos e políticos oferecem visões competitivas de transformação social.

Como nossos casos demonstraram, o desafio decisivo para a política transformadora está em apresentar esta visão sem se tornar visionária. Podemos acrescentar aqui, tomando também como base nossos estudos de caso, que a resposta para esta pergunta jaz nas instituições da responsabilidade política estendida.

$\mathrm{Na}$ visão corrente, é precisamente o caráter episódico da responsabilidade eleitoral que dá aos políticos o espaço de manobra para levar a cabo o programa vencedor que eles haviam oferecido ao eleitorado. Na verdade, alguns têm sustentado que quanto maior o tempo entre eleições, maiores as possibilidades de que os governantes no poder 
sejam capazes de enfrentar a visão do longo prazo e levar a cabo tarefas difíceis, sabendo que eles estão protegidos da responsabilidade no meio tempo (Haggard e Kauffman, 1995, pp.156-159; Geddes, 1994). Desta perspectiva, a visão de longo prazo, junto com a autorização para executála, existem como uma troca pela responsabilidade política no curto prazo.

Da perspectiva da responsabilidade política estendida, ao contrário, a autorização é um processo contínuo, e o político reformador bem-sucedido reconhece que "vender sua visão" requer credenciamento constante ao longo do processo. $\frac{48}{6}$ Ele sabe que quanto mais ambicioso o programa e mais difíceis as tarefas de reformar, maior a incerteza entre os atores da sociedade sobre o presente e o futuro. Assim, enquanto continua a projetar sua visão do futuro, ele se engaja no trabalho político de uma responsabilidade ao longo do processo, fazendo associações entre as preocupações presentes e sua visão transformadora. Precisamente porque o que está em jogo é grande e a incerteza é alta, ele sabe que não pode se basear simplesmente na afirmação: "Através dos seus votos vocês investiram em mim, e agora, investido de minha visão, eu planejo o seu futuro". Ao contrário, ele trabalha para demonstrar sua responsabilidade e batalha por apoio contínuo da opinião pública quase ininterruptamente.

Em situações em que se busca implementar políticas de transformação, o investimento político é um processo múltiplo e complexo. De um lado, ele lembra uma oferta pública inicial supervisionada por uma comissão eleitoral (como uma Comissão de Seguros e Trocas) e subscrita por um partido político (como um importante banco de investimentos). Somente com um programa convincente um partido pode ganhar investidores o bastante para cobrir seus pontos. Mas esta não é a única analogia apropriada a ser feita a partir do mundo dos negócios. Por outro lado, em condições de reforma de alta incerteza, investimentos políticos se parecem com uma frágil carteira de caderneta de poupança de um pequeno banco, cujos executivos devem garantir aos numerosos depositantes que seus investimentos são seguros para que não haja uma corrida de saques, o que seria desastroso tanto para o banco como para os depositantes. Reconhecendo que o apoio público pode ser obtido através de eleições, os políticos reformistas bem-sucedidos continuamente se envolvem no esforço de tradução política: apontando para políticas particulares como evidência da ressonância de visões estratégicas mais amplas, ligando sacrifícios de curto prazo a retornos de longo prazo e garantindo ao público a administração efetiva dos recursos políticos a eles confiados com tanta confiança. Resumindo, eles apontam para um conjunto diverso de "provas" de sua credibilidade.

Mas esta alquimia política não é suficiente para garantir que os investidores individuais vão considerar seus depósitos seguros. Mesmo o contador mais habilidoso não pode garantir ao público que suas contas são gerenciadas de maneira apropriada e que seus interesses estão seguros. $\mathrm{Na}$ verdade, isoladamente estas representações podem levar a uma corrida mobilizatória: passeatas, demonstrações e a proliferação de associações como "provas" de apoio continuado; manipulação aberta da imprensa; demagogia populista que produza curtos-circuitos na cadeia de associações entre o presente e o futuro. Na sua pior forma, os riscos de mobilização antecipam o papel decisivo das eleições. $\mathrm{Na}$ sua forma mais tênue, eles sempre ameaçam um colapso da "confiança dos investidores" e "corridas aos bancos", já que tipicamente acabam por produzir uma espiral de desconfiança.

De forma necessária mas não suficiente, a posse continuada de credibilidade por políticos e partidos políticos é apenas um aspecto da responsabilidade política estendida. Como um programa político não é igual a um título resgatável no longo prazo com um retorno futuro com taxa pré-fixada, ele requer uma relação imediata e pessoal entre o político e o público. São as instituições da responsabilidade política estendida internas e externas ao Estado, nós afirmamos, que convencem os depositantes individuais a manter seus créditos nos políticos reformadores. Mediante o escrutínio público crescente das instituições da responsabilidade horizontal (instituições estatais monitorando instituições estatais), os cidadãos adquirem algumas garantias de que seus investimentos no programa de reforma não são autorizações para ações caprichosas que precipitarão o 
desastre. Através das extensões da responsabilidade política no tempo e em escopo para incluir outras representações organizadas de interesses da sociedade, os cidadãos adquirem algumas garantias de que seus investimentos estão cobertos e são, portanto, resgatáveis.

A extensão da responsabilidade política (horizontalmente a outras instituições estatais; lateralmente a outras instituições de representação política; temporalmente para monitoramento continuado) fornece as salvaguardas institucionais para garantir aos depositantes que os intermediadores políticos não estão gastando seus depósitos de forma irresponsável. Quanto mais estas salvaguardas forem efetivas, mais os depositantes serão capazes de reconhecer que os saldos no banco não são simples apostas, mas depósitos e retiradas normais (assim como o programa político se submete ao processo normal de perder e ganhar apoios entre eleições). Salvaguardas institucionais, portanto, promovem a confiança dos "investidores". Elas tornam possível para o público dar crédito às reformas. Em resumo, a responsabilida de política estendida estende os horizontes temporais dos atores da sociedade.

$\mathrm{Na}$ visão corrente, quanto maior a expansão no tempo entre os episódios de responsabilidade política, maior a capacidade dos políticos reformadores para "mover o mundo". Ao contrário, a responsabilidade política estendida encurta o período entre episódios de responsabilidade. Além disto, como vimos, ela estende os horizontes temporais dos políticos e do público, sugerindo uma variação política do paradoxo de Zenon: da mesma forma que na Grécia antiga os matemáticos reproduziam o infinito pela divisão em frações incrementais cada vez menores, os monitoramentos incrementais provêem a base política das estratégias de longo prazo. Na visão tradicional, quanto maior a concentração de autoridade, mais capaz é o executivo de engendrar as mudanças. Ao contrário, a responsabilidade política estendida resulta de uma rede de autoridade distribuída. Além disto, paradoxalmente, com a inserção do executivo central em um conjunto de instituições autônomas e que se monitoram mutuamente, esta própria distribuição de autoridade reforça a coerência e a efetividade das políticas de reforma. Ela alcança isto multiplicando os pontos de alavancagem no campo da política. A política de transformação é alavancada não simplesmente por meio do alinhamento das mais longas cadeias de aliados, mas utilizando os antagonismos institucionais. As políticas de transformação não utilizam as transições "suaves", mas usam as fricções institucionais $\frac{49}{}$ como pontos de apoio para construir credibilidade junto ao público e ganhar autorização para a promoção das mudanças. Os neo-hobbesianos estão errados. A autoridade e a responsabilidade política não constituem um jogo de soma zero. A responsabilidade política estendida pode aumentar a autoridade para executar reformas.

Repensando a coerência

Por meio dos acordos que amarram deliberações estendidas o político fica comprometido. Atado desta forma, ele está livre para oferecer sua visão institucional pragmatizada: "Eu estou preso ao meu programa e estou preso em uma rede de autoridade distribuída. Vocês podem me autorizar a agir porque eu estou limitado para agir de forma precipitada". É este tipo peculiar de "duplo comprometimento" que abre espaço para a política transformadora - pois é uma combinação distinta de visão e constrangimentos, de programa e de pragmatismo, que resulta em políticas reformistas bem-sucedidas. Se for simplesmente pragmática, uma política de reforma se arrisca a empacar contra interesses entrincheirados. Se for apenas programática, uma política de reforma corre o risco de se tornar prisioneira de suas próprias representações (illusio). São os duplos comprometimentos da responsabilidade política estendida (comprometendo o executivo na rede de autoridade distribuída e o amarrando às responsabilizações sistemáticas do programa de reforma) que resultam em um pragmatismo programático.

A noção de responsabilidade estendida e seu pragmatismo programático concomitante têm implicações para nossa compreensão da coerência. $\mathrm{Na}$ visão convencional, a coerência das políticas é julgada pelas qualidades de consistência interna, precisão e pelo caráter geral do desenho da política. Quanto mais claro, preciso e 
implementado em sua totalidade é o projeto de reforma, mais coerente será a linha de política resultante. Alguns planejadores de políticas econômicas começam a questionar esta visão, ao menos ao atacar a noção de "seqüência fixa". $\underline{50}$ No lugar da metáfora arquitetônica de projeto, nestes casos o desenho da reforma baseia-se em modelos da cibernética, com loopings de retorno e autocorreções construtivas. Como um programa de computador sofisticado, com uma série de subrotinas "se...então" simultâneas, o projetista monitora continuamente um vasto conjunto de indicadores econômicos em um processo de ajustamento contínuo dos principais parâmetros do modelo.

Uma política transformadora se baseia no entendimento do planejamento como processo. Mas além dos indicadores de progresso econômico (nível de inflação, taxas de salário, performance de exportações e outros), ela reconhece que a validade de longo prazo de um programa de reforma depende de fatores não econômicos como os níveis e formas de apoio público, a confiança do mundo dos negócios, o comportamento eleitoral, dentre outros. As instituições da responsabilidade política estendida fornecem este feedback crítico. Mediante associações deliberativas, tanto os políticos como o público calibram os parâmetros de mudança. Fazendo o papel de "institucionalização da razão prática", eles implementam a "regra pragmática" de John Dewey, que diz que "para se descobrir o significado de uma idéia deve-se perguntar por suas conseqüências" (Dewey, 1982, p. 173). $\underline{51}$ Em tal pragmatismo programático, meios e fins estão em relação de causalidade múltipla ou recíproca. Os fins não ditam os meios, já que apenas atingindo os objetivos descobrimos o sentido completo da idéia inicial e através deste aprendizado sobre as implicações dos objetivos calibramos os instrumentos da visão e os instrumentos práticos para um novo estágio futuro de experimentação (Sabel, 1995b, p. 28). Políticas transformadoras são experimentais — não porque a sociedade é o objeto de um desenho fixo e totalizante, mas porque as deliberações "educam o educador", transformam o transformador. Pragmatizando a visão, elas não limitam o campo de visão: ao contrário, elas o abrem, revelam objetivos, convidam à revisão não como um olhar para trás, mas como uma busca de novas percepções do possível.

O pragmatismo programático, portanto, não apenas questiona a seqüência fixa das várias medidas de política em um programa de reforma, como vai além deste ponto de partida para desafiar a seqüência do design da reforma e da implementação das políticas. $\frac{52}{}$ Como tal, ele se parece com a recente reorganização da produção em alguns dos mais destacados setores das economias avançadas, caracterizados por rápidos avanços tecnológicos e extraordinária volatilidade dos mercados. Como identificados por Sabel (1990, 1995a e 1995b; Sabel e Prokop, 1994), estes novos desenvolvimentos mostram duas características distintas. Primeiro, pela presença de fortes vantagens para quem se move primeiro - já que o primeiro ator a introduzir um novo produto (especialmente um que estabeleça um novo padrão industrial) captura um pedaço desproporcional do mercado, por obter crescentes retornos de escala — , as firmas que esperam que o desenho se complete para começar a produzir serão penalizadas na competição. Nestas condições, estratégias bem-sucedidas integram competição e execução, com aspectos significativos do processo de produção começando antes da finalização do desenho. Em segundo lugar, estes novos sistemas de produção são também caracterizados por engenharia simultânea. Enquanto o designconvencional é seqüencial, isto é, os subsistemas considerados centrais são desenhados em detalhe primeiro, estabelecendo as fronteiras para o design dos componentes de mais baixa ordem, na engenharia simultânea, equipes de projetos independentes desenvolvem todos os subsistemas de forma concorrente. Neste tipo dedesign, as várias equipes se engajam em um monitoramento constante e mútuo, já que as inovações produzem propostas múltiplas e às vezes até mesmo competidoras para melhorar o conjunto do projeto (Sabel, 1995b, p. 24). O sucesso na engenharia simultânea, segundo Sabel, depende deste "aprendizado por monitoramento" e requer uma flexibilidade organizacional aguda que sustente, ao invés de reprimir, a ambigüidade durante o processo inteiro. 
Este conceito de design como deliberação no interior de setores líderes das economias avançadas corresponde, de maneira próxima, à nossa concepção das fontes de coerência nas estratégias de reforma em economias póssocialistas. Nesta visão, a coerência das políticas não é uma função direta da totalidade ou precisão do desenho original, mas de uma integração entre desenho e implementação. Assim como na engenharia simultânea, a política transformadora sustenta a ambigüidade com o propósito de clarificar os objetivos por meio de um processo deliberativo. Nem sem objetivos, nem rígido, o processo tentativo de diálogo através do qual os objetivos são estabelecidos e suas implicações reconhecidas facilita o aprendizado a partir das condições mutantes surgidas com os esforços de reforma. A coerência política é, assim, o produto de um aprendizado reflexivo.

O leitor não deve, no entanto, nos compreender mal, entendendo que invocando o conceito de "aprendizado" temos em mente um processo de contemplação silenciosa. $\mathrm{Na}$ verdade, como nossos casos revelam, especialmente os mais bem-sucedidos, o processo de responsabilidade política estendida é barulhento e conflituoso. Onde as deliberações são reais, os interesses não são facilmente conciliáveis. Eles cantam em tons diferentes, eles calculam em racionalidades diferentes, eles se utilizam de diferentes princípios de legitimação. Os fóruns deliberativos não são domínios para suprimir estas diferenças, mas para que elas se expressem. A estratégia de exclusão acalma o embate barulhento mas sacrifica a coerência das políticas. A estratégia da inclusão pode parecer discordante, mas promove a reflexividade organizacional, que é a base da adaptabilidade de longo prazo (Stark, 1996, pp. 1.0211.022).

\section{NOTAS}

1 Estes pontos de partida inexistentes nos lembram de uma piada sobre um irlandês no interior a quem alguém pergunta: "Qual a melhor forma de se chegar a Dublin?".
Depois de pensar por um momento, ele responde: "Não comece daqui". A ironia de nosso irlandês é apropriada aos europeus do Leste, que sabem que todas as melhores formas para se chegar ao capitalismo têm início em outro lugar. Nossa abordagem recoloca a pergunta: ao invés de "qual o melhor caminho para o capitalismo?", perguntamos: "Como podemos começar daqui?".

$\underline{2}$ Nossa análise indicou que as redes húngaras são formadas predominantemente por ligações de empresa a empresa, em alguns casos envolvendo bancos mas com a ausência de vínculos entre bancos e instituições de nível intermediário como empresas de investimento. O caso tcheco é um oposto espelhado. Na Hungria as redes de propriedade são formadas predominantemente por vínculos no nível intermediário entre bancos e fundos de investimento, mas conexões diretas de propriedade entre as próprias empresa são raras. Utilizando a linguagem da análise de redes, podemos dizer que enquanto as redes de empresas húngaras são unidas densamente no nível das empresas mas ligadas frouxamente no nível intermediário, as redes de empresas tchecas são unidas de maneira tênue no nível das empresas mas são fortemente conectadas no nível intermediário.

$\underline{3} \mathrm{Na}$ Hungria, uma reorganização de fato descentralizada dos ativos combinou-se com o gerenciamento centralizado dos passivos, levando a uma nova forma de paternalismo. Sob o socialismo de Estado, o paternalismo cresceu a partir do gerenciamento centralizado dos ativos; sob o póssocialismo, o paternalismo originou-se do gerenciamento centralizado dos passivos.

4 As políticas alemãs nos novos Länders da antiga Alemanha Oriental são descritas em detalhes em Stark e Bruszt (1998, cap. 6). [N. do T.: Os Länders são o correspondente aos governos estaduais brasileiros.]

$\underline{5}$ Jawiga Staniszkis desenvolveu o conceito de gerenciamento através de crises em sua análise das mudanças cíclicas das políticas econômicas do socialismo de Estado. Ver Gross (1984, pp. 249-277). 
6 Entre outros, Williamson (1994), Geddes (1994), Haggard e Kaufman (1995), Holmes (1993) e Callaghy (1995).

1 Assim, essa literatura enfatiza as "estruturas de incentivos" (por exemplo, a segurança no cargo) dos governantes durante o mandato. Ver Geddes (1994, especialmente p. 190), Haggard e Webb (1994) e Alesina (1994).

8 Barbara Geddes (1995) apresenta uma clara e vigorosa afirmação desta reformulação. Joel Hellman (1995) expressa esta mudança como a de um "dilema de participação" para um "dilema de contestação".

9 Geddes (1994), por exemplo, enfatiza a autoridade presidencial e nota suas limitações em sistemas partidários fragmentados, coalizões governamentais indisciplinadas e burocracias incompetentes e não leais.

10 Haggard e Kaufman (1995) enfatizam a necessidade de autoridade executiva forte na proposição das reformas. Uma vez que as reformas estejam sendo realizadas e comecem a produzir benefícios, é possível (e, para eles mesmo, desejável) incluir grupos sociais mais amplos no processo de produção das políticas.

11 Estes resultados não surpreenderão as pessoas familiarizadas com o argumento de Douglas North e Barry Weingast (1989): amarras institucionais que limitam a arbitrariedade do soberano podem aumentar a credibilidade e a autoridade efetiva. Elaboramos uma visão similar sobre a importância da autoridade "inserida" do executivo em nossa seção conclusiva. Sobre a noção geral de constrangimentos benéficos ver Streeck (no prelo).

12 As presentes características do parlamentarismo húngaro foram fortemente influenciadas pelo chamado Pacto Parlamentar, lançado na primavera de 1990 entre o MDF (o vencedor das primeiras eleições livres) e o SzDSz (o mais forte partido de oposição). Em troca da Presidência (eleita pelo Parlamento e ocupada pelo candidato do SzDSz, Árpád Gönz), os Democratas Livres cederam seu direito de desafiar o governo através de voto parlamentar de maioria nessa legislatura. A conseqüencia constitucional do pacto foi a adoção do parlamentarismo no país, ao invés do regime presidencialista. Com clara prioridade para questões de governabilidade sobre participação, os novos arranjos institucionais não apenas aboliram a cláusula de dois terços que teria dado poder de veto de jure à oposição parlamentar, mas também, ao introduzir o voto positivo de desconfiança, enfraqueceram os poderes de controle do parlamento e fortaleceram a posição central do primeiroministro.

13 Ao contrário da República Tcheca, onde uma confederação unitária de sindicatos representa os interesses do trabalho, na Hungria há sete confederações de sindicatos que organizam cerca de $25-30 \%$ dos trabalhadores, isto é, têm aproximadamente metade do nível de organização dos sindicatos tchecos. Na Hungria, a antiga confederação de sindicatos reformada (MSZOSZ) da era comunista mantém-se como a mais forte confederação, organizando principalmente os setores mais atingidos pelas reformas de mercado. Duas organizações dissidentes dos sindicatos unificados do período comunista representam as diferentes facções da burocracia estatal, e uma terceira une trabalhadores da indústria química e outros pequenos sindicatos setoriais que não aceitaram entrar para a MSZOSZ. Três novas confederações de sindicatos foram formadas depois de 1988, sendo a Liga Democrática dos Sindicatos Independentes a mais forte delas. Juntamente com o Conselho de Trabalhadores e a muito menor Confederação Solidariedade, as novas organizações congregam cerca de $15-20 \%$ dos trabalhadores húngaros.

14 Os aspectos do caso húngaro serão desenvolvidos com maior detalhe mais adiante, na discussão comparativa dos casos nacionais.

15 Sobre a origem do sistema político alemão do pós-guerra ver Rogers (1993) e Bawn (1993). 
16 Sobre o vivo debate entre acadêmicos alemães acerca da propriedade da aplicação da noção de colonialismo ao processo de unificação ver Pickel (1992) e Brie (1994).

17 Escrevendo sobre as instituições políticas alemãs neste período de exceção, Gerhard Lehmbruch, um destacado observador, nota: "O que aconteceu no início de 1990 foi a quebra temporária dos elos da estrutura quase corporativista da rede de políticas da Alemanha Ocidental. Sob as circunstâncias extraordinárias de 1990, o sistema partidário cortou seus canais de comunicação com os outros atores corporativistas da política alemã e assumiu a postura de um executivo soberano não constrangido. Isto teve a conseqüência adicional de que seus sistemas de crenças peculiares, que normalmente servem a propósitos de integração ao invés de operativos, passaram a governar suas escolhas de política operativa. O sistema de crenças que dominava não apenas o discurso eleitoral em 1990, mas também as decisões do governo era o mito da ‘economia social de mercado' em uma versão extremamente simplificada". Cf. Lehmbruch (1992, pp. 45-46). Ver também von Beyme (1992).

18 Sobre a interpenetração de redes de políticas públicas no período pós-guerra (mas antes da unificação), que impediu o "Estado semi-soberano" de realizar decisões unilaterais e o obrigou a negociar o conteúdo das políticas públicas, ver Katzenstein (1987).

19 Ao contrário da Hungria e do resto do mundo póssocialismo, onde milagres nunca tiveram credibilidade e portanto nunca foram prometidos, garantiu-se aos alemães orientais que os custos sociais da reestruturação não seriam grandes, e aos alemães ocidentais, que a divisão dos custos fiscais não seria excessiva. Para uma discussão abrangente da política dos "custos de unificação" ver Seibel (s/d).

20 Hyman (1996, p. 20), no entanto, registrou uma queda na filiação a sindicatos nos anos seguintes, declinando para 2,6 milhões o número de sindicalizados no início de 1995 (uma perda de 38\% relativamente ao número máximo alcançado).
21 Estes incluíam, entre outros, o "Grundsätze zur Zusammenararbeit von Bund, neun Länders, und Treuhandantalt" (Guia para a cooperação entre o governo federal, os novos Länders e o Treuhand), expedido em 14 de março de 1991, que estabelecia reuniões regulares entre os líderes do THA e os ministros dos governos estaduais da Alemanha Oriental; o "Gemeinsame Erklärung", entre a DGB, o sindicato dos trabalhadores do setor público alemão e o Treuhand, em 13 de abril de 1991; e o Acordo sobre as Sociedades de Promoção do Trabalho, Emprego e Desenvolvimento Estrutural, de 17 de julho de 1991. Cf. Seibel (1993, pp. 292-293).

22 Embora não tenha obtido maioria, o novo partido de Klaus foi capaz, rapidamente, de reivindicar a pluralidade no parlamento. O problema, no entanto, foi que, não obstante o ODS tivesse conseguido ganhar apoio crescente dentre os membros do parlamento, ele continuava sem legitimidade eleitoral para fazer um assalto direto e decisivo contra os socialistas, os social-democratas e os "sixtyeighters" (ativistas políticos da Primavera de Praga em 1968), que juntos compunham a maioria do governo no início da fase pós-socialista.

23 Orenstein afirma que o "caráter híbrido socialdemocrata" do primeiro pacote de reformas foi o resultado de um compromisso alcançado através de discussão entre os dois grupos presentes no interior do governo: "Enquanto Vaclav Klaus e sua equipe de neoliberais no Ministério das Finanças planejavam a privatização em massa, liberalização de preços e estabilização monetária, os reais social-democratas presentes no Ministério do Trabalho planejavam e implementavam a dimensão socialdemocrata da reforma" (Orenstein, 1996, p. 84).

24 Barry Weingast (1995) apresenta uma sólida defesa dos benefícios do federalismo na transformação econômica. Ver também Montinola, Qian e Weingast (1995).

25 Ver, por exemplo, "We cannot allow a wave of bankruptcies" (entrevista com Karel Dyba, ministro da Política Econômica e Desenvolvimento), Zemedelske Noviny, 29/1/1993, p. 6; e "Bankruptcies under supervision: the 
law on bankruptcies and settlements to be softned", Hospodarske Noviny, 12/2/1993, pp. 1-2 (Joint Publications Research Service, East European Reports, JRPS-EER-93-021-S, 19/3/1993). Ver também Haryi e Dermott (1995).

26 Peter Rutland afirma que os aluguéis cobrem apenas $20 \%$ dos custos de manutenção e que o aquecimento e a eletricidade são altamente subsidiados. Nesta situação, a indústria de mineração faz lobby para aumentar o preço do carvão, serviços públicos clamam por maiores tarifas e os recentemente restituídos proprietários privados dos blocos de apartamentos demandam o direito de cobrar aluguéis de nível de mercado de seus inquilinos: "Apesar destas diversas pressões por liberalização de preços (todas de impecável lógica thatcheriana), Klaus tem permitido apenas uma elevação suave nos aluguéis, por medo de detonar protestos sociais. Em 1992, os subsídios somavam 4,8 milhões de coroas. Em dezembro de 1993, um novo programa foi introduzido gerando 250 coroas (8 dólares americanos) por mês de subsídio para perto de meio milhão de inquilinos de baixa renda." (Rutland, 1994, p. 11).

27 "O fator chave no nosso sucesso tem sido a clara visão do futuro que nós queremos atingir e a pragmática e possível estratégia de reforma capaz de ganhar o apoio da maioria da população." (Vaclav Klaus, 1996, p. 3; ênfase nossa). Ver ainda Klaus (1994).

28 Com a regra de exclusão dos $5 \%$ (segundo a qual os partidos que recebessem menos de $5 \%$ dos votos seriam excluídos da divisão dos assentos parlamentares), a coalizão governamental alcançou sua maioria de $52 \%$ com $42 \%$ dos votos (Eastern European Constitutional Review, 3(2), primavera de 1994, número especial: "Designing electoral regimes", p. 65). Sobre as caraterísticas peculiares da lei eleitoral tcheca, ver o trabalho instigante de David Olson (1993).

29 "Országos Választási Bizottsága az Országgyülési Képviselök Választásról". Magyar Köz̨löny, 44, 1990.

30 Sobre as eleições húngaras de 1990 e 1994, ver Szelényi, Szelényi e Poster (1996).
31 Ver Myant (1994, pp. 64-67) para uma discussão sobre mobilização trabalhista durante o período.

32 Confirmando nosso argumento inicial de que a formação das políticas econômica e social não pode ser analisada isoladamente da questão da separação tcheca e eslovaca, devemos ressaltar que estes direitos foram mais solidificados no decorrer do "Divórcio de Veludo". No período imediatamente anterior à separação formal, ocorrida em primeiro de janeiro de 1993, a nova Constituição tcheca teve de ser rascunhada e rapidamente ratificada para providenciar o arcabouço legal para o Estado emergente. Esta ratificação requeria a maioria qualificada (de dois terços). Em troca do seu apoio, o Partido Social-Democrata tcheco exigiu que a Carta Européia de Direitos e Liberdades fosse incluída na nova Constituição. Este documento, fornecendo um amplo conjunto de direitos sociais, foi, na verdade, anexado à Constituição tcheca. Orenstein (1996, p. 98) observa: "Enquanto a Inglaterra de Thatcher decididamente pulou o 'capítulo social', a Constituição Européia de Direitos e Liberdades é hoje lei na República Tcheca. Como os socialdemocratas adoravam dizer na época, 'nós somos o meio da Europa, não as ilhas britânicas"'. O legado da separação continuou, portanto, a dar forma às políticas econômica e social.

33 Para uma discussão acerca das tensões no interior do órgão tripartite, das afirmações da parte dos sindicatos de que o governo não manteve sua parte nos acordos, e uma descrição das várias greves de advertência para fazer as negociações serem retomadas, ver Myant (1994, pp. 68-72).

34 Economist Intelligence Unit., Country profile: Czech Republic and Slovakia - 1995-96; dados de desemprego (pp. 14 e 41); dados de turismo (p. 22). Os níveis dramaticamente baixos de desemprego na República Tcheca também são explicados por critérios de elegibilidade restritiva e benefícios limitados (em termos de duração e nível) para o desemprego. $\mathrm{Na}$ Hungria, ao contrário, os benefícios de desemprego são mais substanciais e os custos do emprego maiores graças às taxas extraordinariamente altas de contribuição ao seguro social 
por parte dos empregadores. Na Hungria, um dentre dois trabalhadores dispensados é registrado como desempregado, ao passo que na República Tcheca apenas um dentre três entra nas filas dos desempregados. Isto dito, devemos acrescentar que as taxas de dispensa têm sido muito mais baixas na República Tcheca: de 1990 a 1994, os níveis de emprego na Hungria caíram em $26 \%$, ao passo que na República Tcheca este declínio foi de aproximadamente 10\%. Além disto, através da criação de novos postos de trabalho e mantendo os custos totais do trabalho baixos, o desemprego de longo curso é significativamente mais baixo na República Tcheca, e a taxa que mede o retorno dos desempregados ao status de empregados é seis vezes maior na República Tcheca do que na Hungria. Ver Koltany (s/d.).

35 Myant (1994, pp. 75-80) apresenta um excelente panorama dos diferentes níveis de apoio para o programa de reforma do governo nos diversos segmentos do movimento sindical.

36 Apenas algumas semanas depois de sua afirmação hiperbólica sobre a mobilização sindical da primavera de 1994, Klaus aceitou o convite para dar uma conferência no congresso sindical, oferecendo o seguinte "ramo de oliveira": "O governo procura um consenso básico dos cidadãos em assuntos fundamentais do presente e do futuro e está consciente do fato de que os sindicatos têm um papel excepcionalmente importante. Conseqüentemente, nós respeitamos o Conselho para Acordo Econômico e Social e tentaremos no futuro negociar neste contexto, embora o papel do governo (e do Estado) como empregador, graças à privatização, esteja mudando fundamentalmente. Nós continuaremos a fazer sugestões para futuras mudanças nas negociações tripartites, mas eu gostaria de enfatizar aqui, em frente a vocês, que nós não estamos chamando para uma revolução, nem para mudanças radicais. Diferenças de opinião que venham a aparecer sobre estes assuntos não devem, portanto, na minha opinião, ser dramatizadas." (apud Orenstein, 1994, pp. 20-21).
37 Conhecemos muito bem as possíveis objeções estruturalistas à nossa abordagem institucionalista. Uma abordagem estruturalista afirma que as diferenças de política entre os casos húngaros e tcheco são explicadas de forma mais parcimoniosa pelas diferenças entre as condições econômicas de fundo: por exemplo, dívida externa extraordinária no caso húngaro e ausente no caso tcheco. Mas esta explicação falha porque os resultados que poderíamos prever desta lógica não combinam com o desenvolvimento realmente ocorrido. Com maior espaço econômico de manobra, seria de se prever que os tchecos (especialmente dadas as suas preferências de políticas iniciais) se movessem com maior rapidez; no entanto, seu comportamento tem sido moderado. Enfrentando constrangimentos econômicos mais severos, seria de se esperar que os húngaros (especialmente considerando suas tendências gradualistas iniciais) iriam proceder com cautela; entretanto, eles se precipitaram, provocando uma severa crise financeira que exacerbou sua dívida externa. De forma similar, a partir do caráter não reformado da antiga economia socialista da República Tcheca, seria de se antecipar maiores problemas estruturais de ajustamento (níveis mais altos de dispensas e desemprego, por exemplo) do que na Hungria, onde as condições microeconômicas no nível das firmas pareciam mais auspiciosas. Nossos esforços ao longo deste artigo têm sido no sentido de explicar as políticas estatais a partir das características dos ambientes políticos que as produziram.

38 Nossa comparação entre os casos húngaro e tcheco encontra um interessante contraponto. Durante a última década, os governos trabalhistas tanto da Austrália como da Nova Zelândia introduziram reformas neoliberais radicais. Mas como seus contrapontos do Leste Europeu, as características institucionais dos dois sistemas exibiam importantes diferenças. Como na Hungria, a autoridade executiva na Nova Zelândia é altamente concentrada e relativamente não constrangida (com um parlamento unicameral e um sistema eleitoral em que o vencedor leva tudo). Além disso, como na Hungria, os políticos trabalhistas na Nova Zelândia se comportaram de forma unilateral, rejeitando consultas com o trabalho organizado. 
Ao contrário, os maiores constrangimentos do parlamento bicameral e da divisão de poderes do federalismo australiano (como na República Tcheca) produziram políticas mais moderadas e incrementais, baseadas em acordos de cooperação formalizados entre o governo e o Conselho Australiano de Sindicatos. Do ponto de vista do nosso argumento, não é surpreendente que na Austrália as reformas econômicas sejam mais sustentáveis, e que na Nova Zelândia elas apresentem sinais de que serão revertidas. Ver o conjunto fascinante de estudos apresentados em Castles, Gerritsen e Vowles (1996).

39 Hana Pitkin (1967, pp.55-59) apresenta um lúcido contraste entre a "visão da autorização" de Hobbes e a "visão da responsabilidade política". Para uma atualização destas questões ver March e Olsen (1995).

$\underline{40}$ Guiillermo O'Donnell, quase parafraseando os Federalist papers, afirma em defesa da responsabilidade política horizontal: "Porque as políticas são executadas através de uma série de poderes relativamente autônomos, o processo de decisão na democracia representativa tende a ser lento e incremental e algumas vezes inclinado a impasses. Mas por este mesmo processo, estas políticas são normalmente vacinadas contra erros grosseiros, e elas têm uma razoável probabilidade de serem implementadas; além disto, a responsabilidade por erros tende a ser amplamente repartida." (O'Donnell, 1994, p. 62).

41 Como vimos no caso húngaro apresentado anteriormente, e como exemplifica o estilo crescentemente delegativo de Yeltsin (de governo por decreto), estes esforços para usar a própria crise como legitimação para a expansão do poder executivo são endêmicos nas sociedades que têm falta de responsabilidade política estendida. As observações de O'Donnell sobre a "democracia delegativa" na América Latina poderiam ter sido escritas sobre o caso dos países pós-socialistas: "a crise [social e econômica profunda] gerou um forte sentimento de urgência e promoveu terreno fértil para desatrelar as disposições favoráveis do legislativo que podem estar presentes em um dado país. Problemas e demandas se amontoaram em frente a governos inexperientes que tiveram que operar através de uma burocracia fraca e desarticulada (e não leal). Presidentes foram eleitos prometendo que eles, sendo fortes, corajosos, se situando acima de partidos e interesses, machos, iriam salvar o país. Seus governos são 'governos de salvadores da pátria'. Isto levou a um estilo 'mágico' de produção de políticas: o mandato delegado supostamente entregue pela maioria, forte vontade política e conhecimento técnico que seriam suficientes para preencher a missão do salvador — os 'pacotes' se seguiram como um corolário" (O'Donnell, 1994, p. 65).

42 "Na democracia delegativa, presenciamos um processo decisório errático e frenético, que na América Latina denominamos 'decretismo'. Como as ordens unilaterais e inesperadas do executivo com maior probabilidade atacam interesses importantes e politicamente organizados, elas têm baixa probabilidade de implementação. No meio de uma crise séria e de uma crescente impaciência popular, o resultado é normalmente uma nova onda intempestiva de decisões que, graças à experiência que a maioria dos setores da sociedade já adquiriu em resistir às iniciativas anteriores, tem ainda menor probabilidade de vir a ser implementada". Cf. O'Donnell (1994, pp. 66-67).

43 As semelhanças e diferenças entre nosso conceito de responsabilidade política estendida e a noção de "inserção expandida" são elaboradas em Stark e Bruszt (1998).

$\underline{44} \mathrm{Na}$ Hungria, ao contrário, onde os interesses do trabalho e das localidades foram excluídos, as políticas transformaram-se em crises com uma rapidez proporcional à velocidade do processo de decisão. Naquele caso, os interesses empresariais, também excluídos da participação aberta e pública na formulação das políticas, encontraram mais tarde a porta de trás para falir o Estado quando ele reverteu o seu curso.

45 Este é o perigo da "inserção expandida" de Evans. Uma das principais diferenças com relação ao nosso conceito está em que, enquanto Evans vê os benefícios que advêm da inserção do pessoal da burocracia estatal em redes sociais de vínculos pessoais, nós destacamos a forma pela 
qual os centros de produção de decisões estão inseridos como organizações em redes de instituições políticas. Este conceito institucional de inserção é portanto similar ao de North e Weingast (1989), Katzenstein (1987) e Streeck (no prelo).

46 Para uma análise das patologias do campo político democrático que corrigem a falta relativa de habitus e práticas dos políticos, ver especialmente O'Donnell (1993). Herbert Kitschelt (1995) apresenta uma análise comparativa das propriedades do campo político póscomunista. Ver ainda Kitschelt (1996).

47 Os analistas que tendem a enfocar os elos fortes de uma rede de produção de idéias — isto é, onde os blocos de idéias constituintes estão ligados de maneira muito próxima e em padrões densos - chamam estas formas de "ideologias" (para a formulação clássica ver Bendix, 1956). Os analistas que enfatizam a qualidade (compreensível mas não abrangente) das formas enfocam os elos fracos em uma rede de produção de idéias, como enfatizado no uso do termo "histórias" e em uma especial atenção para a estrutura narrativa (White, 1992; Sabel e Zeitlin, no prelo). Ideologias são como mapas rodoviários, mostrando as conexões abrangentes, ao passo que histórias são como caminhos e picadas, contando como alguém foi daqui até ali por meio de uma certa cadeia de conexões.

48 Comentando uma conversa com Leszek Balcerowick, Vaclav Klaus ressalta seu próprio engajamento na política do dia-a-dia: "Quando ele me visitou pela última vez [...] eu o perguntei quantas vezes por semana ele viajava pela Polônia e falava em praças, em centros culturais, em estádios, com o objetivo de ganhar o maior apoio possível para o seu plano. Ele me revelou que ele preferia ficar sentado em seu escritório preparando documentos. Eu tenho ido a reuniões em média duas vezes por semana e agora, depois das eleições, digamos seis vezes. Eu acho que mais do que qualquer outra coisa, a Polônia está pagando a inabilidade de certos políticos de ganhar este apoio dos eleitores e sua incapacidade de obter poder suficiente para continuar as reformas." (apudOrenstein, 1996, p. 73).
49 Sobre a noção de fricção institucional como fonte de inovação ver Grabher e Stark (1997).

$\underline{50}$ Ver especialmente Peter Murrell (1995) para uma discussão fascinante destas questões.

$\underline{51} \mathrm{O}$ conceito de institucionalização da razão prática é originário de Sabel (1995b).

$\underline{52}$ "É também importante ter em mente que a reforma não é uma questão teórica. Ela ocorre em condições reais, ela afeta interesses reais e vitais de grupos particulares e estratos da população e estes interesses se refletem na política. Isto significa que tentativas de seguir um plano ideal engendrado isoladamente não são simplesmente possíveis de executar no mundo real.[...] Eu nunca pensei em termos do 'melhor possível' ou da 'segunda melhor' política. Isto é uma construção teórica e irreal. Nós sabíamos que nem a estratégia de reforma perfeita nem um conjunto ótimo de políticas pode ser inventado de antemão e simplesmente introduzido a partir de então." Entrevista com Vaclav Klaus em Blejer e Coricelli (1996, pp. 79 e 91).

\section{BIIBLIOGRAFIA}

ALESINA, Alberto. (1994), "Political models of macroeconomic policy and fiscal reforms", in S. Haggard e S. Webb (orgs.), Voting for reform, Nova York, Oxford University Press, pp. 37-61.

BAWN, Kathleen. (1993), "The logic of institutional preferences: German electoral law as a social choice outcome", American Journal of Political Science, 37(4): 965-991.

BENDIX, Reinhard. (1956), Work and authority in industry. Berkeley, University of California Press.

BLEJER, Mario e CORICELLI, Babrizio. (1996), The making of economic reform in Eastern Europe: conversations with reformers in Poland, Hungary and the Czech Republic. Edward Elgar. 
BOURDIEU, Pierre. (1991), "Political representation: elements for a theory of the political field" e "Delegation and political fetishism", in Pierre Bourdieu, Language and symbolic politics, Cambridge, Harvard Univeristy Press, pp. 171-220.

BRIE, Michael. (1994), "Die Ostdeutschen auf dem Wege vom 'armen Bruder' zur organisierten Minderheit?".Working papers series, Arbeitsgruppe Transformationsprozesse, Berlim, Max-PlanckGessellschaft.

BROM, Karla e ORENSTEIN, Mitchell. (1994), "The privatized sector in the Czech Republic: government and bank control in a transitional economy". Europe-Asia Studies, $46(6$.

BRUSZT, Laszlo. (s/d.), The Antall government and the unions. Mimeo.

CALLAGHY, Thomas. (1995), "Africa: back to the future?", in Larry Diamond e Marc Plattner (orgs.), Economic reform and democracy, Johns Hopkins University Press, pp. 140-152.

CASTLES, Francis G., GERRITSEN, Rolf e VOWLES, Jack (orgs.). (1996), The great experiment: labor parties and public policy transformation in Australia and New Zealand. Auckland, Auckland University Press.

DEWEY, John. (1982), "Reconstruction in Philosophy", in John Dewey: middle works, vol. 12, Carbondale, Southern Illinois University Press.

FICHTER, Michael. (1993), "A house divided: a view of German unification as it has affected organized labor".German Politics, 2(1):21-39.

(1994), Institutional transfer and institutionalization in unified Germany: the case of the unions. Trabalho apresentado na Conferência sobre Política Econômica na Nova Alemanha, Itaca, Cornell University.
FICHTER, Michael e REISTER, Hugo. (1995), Zum Stand der Gewerkschaftssentwicklung in Den neuen Bundeslandern: Afbau-Struktur-Politik. Berlim, Relatório de pesquisa preparado para o Comitê para a Pesquisa sobre Mudanças Sociais e Políticas nos Novos Länders Alemães.

GEDDES, Barbara. (1994), Politician's dilemma: building state capacity in Latin America. Berkeley, University of California Press.

(1995), "Challenging the conventional wisdom", in Larry Diamond e Marc Plattner (orgs.), Economic reform and democracy, Johns Hopkins University Press, pp. 59-73.

GRABHER, Gernot e STARK, David. (1997), "Organizing diversity: evolutionary theory, network analysis and postsocialist transformations", in Gernot Grabher e David Stark (orgs.), Restructuring networks: legacies, linkages and localities in post-socialism, Oxford, Oxford University Press.

GROSS, Jan T. (org.). (1984), Poland's self-limiting revolutions. Princeton, Princeton Univesity Press.

HAGGARD, Stephan e KAUFMAN, Robert. (1995), The political economy of democratic transitions. Princeton, Princeton University Press.

HAGGARD, Stephan e WEBB, Steven. (1994), "Introduction", in S. Haggard e S. Webb (orgs.), Voting for reform, Nova York, Oxford University Press, pp.1-36.

HARYI, Aydin e McDERMOTT, Gerald. (1995), Restructuring in the Czech Republic: beyond ownership and bankruptcy. Praga, CERGE-EI, manuscrito.

HELLMAN, Joel. (1995), Political power and economic reform in the post-communist transitions. Cambridge, Harvard University, manuscrito.

HOLMES, Stephen. (1993), "The post-communist presidency". East European Constitutional Review, 2(3):36-41. 
HYMAN, Richard. (1996), Institutional transfer: industrial relations in Eastern Germany. University of Warwick, manuscrito.

KATZENSTEIN, Peter. (1987), Policy and politics in West Germany: the growth of a semi-sovereign state. Philadelphia, Temple University Press.

KITSCHELT, Herbert. (1995), "Formation of party cleavages in post-communist democracies". Party Politics, 1(4): 447-472.

(1996), Post-communist democracies: do party systems help of hinder democratic consolidation? Trabalho apresentado na Conference on Democracy, Markets and Civil Societies in Post-1989 East Central Europe, promovida pelo Centre for European Studies, Harvard, 17-19 de maio.

KLAUS, Vaclav. (1994), "The experience with radical economic reforms in the Czech Republic". The Brown Journal of World Affairs, primavera:123-127. . (1996a), "Entrevista". OECD Transition Brief, 2:3. (1996b), "Entrevista", in Mario Blejer e Babrizio Coricelli (orgs.), The making of economic reform in Eastern Europe: conversations with reformers in Poland, Hungary and the Czech Republic, Edward Elgar.

KOLTAY, Jenö. (s/d.), "Munkanélküli és foglalkoztatáspolitika Közép és Kelet Európban" [Políticas de desemprego e emprego na Europa Central e do Leste]. Közgazdasági Sžemle, 2:142-167.

LEHMBRUCH, Gerhard. (1992), "The institutional framework of German regulation", in Kenneth Dyson (org.), The politics of German regulation, Aldershot, Dartmouth.

MARCH, James e OLSEN, Johan. (1995), Democratic governance. Nova York, The Free Press.
McSHANE, Denis. (1993), "IG Metall — Ossis fight back". New Statesman and Society, 6:10-12.

MONTINOLA, Gabriella, QIAN, Yingyi e WEINGAST, Barry. (1995), "Federalism, chinese style: the political basis for economic success in China". World Politics, 48(1):50-81.

MURRELL, Peter. (1995), "The transition according to Cambridge, Mass.". The Journal of Economic Literature, vol. XXXIII, 1, March. 164-178.

MYANT, Martin. (1994), "Czech and Slovak trade unions", in Michael Waller e Martin Myant (orgs.), Parties, trade unions and society in East-Central Europe, Essex, Frank Cass.

NORTH, Douglas e WEINGAST, Barry. (1989), "Constitutions and commitment: the evolution of institutions governing public choice in seventeenth-century England". The Journal of Economic History, 64(4):803-832.

O'DONNELL, Guillermo. (1993), "On the state, democratization and some conceptual problems: a latinamerican view with glances at some post-communist countries". World Development, 21(8):1.355-1.369.

(1994), "Delegative democracy". Journal of Democracy, 5(1.

OLSON, David. (1993), The sundered state: federalism and parliament in Czechoslovakia. Trabalho apresentado na Conference on Comparative Parliamentary Development in Eastern Europe and the Former USSR, realizada no Center for Soviet, Post-Soviet and East European Studies, Emory University, Atlanta.

ORENSTEIN, Mitchell. (1994), The Czech Tripartite Council and its contribution to social peace. Yale University, manuscrito.

.(1996), Out of the red: building capitalism and democracy in post-communist Europe. Tese de doutoramento, Yale University. 
PICKEL, Andreas. (1992), "Jump-starting a market economy: a critique of the radical strategy for economic reform in the light of East German experiences". Studies in Comparative Communism, 25(2):177-191.

PITKIN, Hana. (1967), The concept of representation. Berkekey, University of California Press.

ROGERS, Daniel. (1993), "Transforming the German party system: the United States and the origins of political moderation". Journal of Modern History, 65(3): 512-532.

RUTLAND, Peter. (1994), Workers' response to the market transition: the Czech case. National Council for Soviet and East European Research, Working Paper.

RYCHETNIK, Ludek. (1995), "Can the Czech Republic develop a negotiated economy?", in Jerzy Hausner, Bob Jessop e Klaus Neilsen (orgs.), Strategic choice and path dependency in post-socialism: institutional dynamics in the transformation process, Aldershot, Edward Elgar.

SABEL, Charles F. (1990), "Moebius-strip organizations and open labor markets: some consequences of the reintegration of conception and execution in a volatile economy", in Pierre Bourdieu e James Coleman (orgs.), Social theory for a changing society, Russel Sage Foundation, pg. 23-54.

(1995a), Intelligible differences: on deliberate strategy and the exploration of possibility in economic life. Trabalho apresentado no $36^{\circ}$ Encontro Anual da Societá Italiana degli Economisti, Florença, Itália.

(1995b), Design, deliberation and democracy: On the new pragmatism of firms and public institutions. Trabalho apresentado na Conference on Liberal Institutions, Economic Constitutional Rights and the Role of Organizations, promovida pela European University Institute, Florença, Itália.

SABEL, Charles F. e PROKOP, Jane. (1994), "Stabilization through reorganization? Some preliminary implications of Russia's entry into world markets in the age of discursive quality standards", in Roman Frydman, Cheryl Gray e Andrzej Rapaczynski (orgs.), Corporate governance in Central Europe and Russia, vol. II: Insiders and the state, Budapeste/Londres, Central European University Press, pp. 151-191.

SABEL, Charles e ZEITLIN, Jonathan. (no prelo), "Stories, strategies and structures: Rethinking historical alternatives to mass production", in Charles Sabel e Jonathan Zeitlin (orgs.), Worlds of possibility: flexibility and mass production in Western industrialization, Paris, Maison de Sciences de l'Homme.

SALLY, Razeen e WEBBER, Douglas. (1994), "The German solidarity pact: a case study in the politics of the unified Germany". German Politics, 3(1).

SCHWARTZ, Herman. (1993), "The new East European constitutional courts", in A.E.Dick Howard (org.), Constitution-making in Eastern Europe, Baltimore, Johns Hopkins Press, pp. 163-207.

SEIBEL, Wolfgang. (s/d.), Unintended consequences. Mimeo. . (1993), Privatization in Eastern Germany. Mimeo.

STARK, David. (1996), "Recombinant property in East European capitalism". American Journal of Sociology, 101:9931.027.

STARK, David e BRUSZT, Laszlo. (1998), Post-socialist pathways: transforming politics and property in Eastern Europe. Cambridge, Cambridge University Press.

STREECK, Wolfgang. (no prelo), "Beneficial constraints: on the economic limits of rational voluntarism", in J. Roger Hollingsworth e Robert Boyer (orgs.), Contemporary capitalism: the embeddedness of institutions, Nova York/Cambridge, Cambridge University Press.

SZELÉNYI, Szonja, SZELÉNYI, Iván e POSTER, Winifred R. (1996), "Interests and symbols in pos- 
communist political culture: the case of Hungary". American Sociological Review, 61(1): 466-477.

VON BEYME, Klaus. (1992), "The effects of reunification on German democracy". Government and Opposition, 27(2):158-177.

WEINGAST, Barry. (1995), "The economic role of political institutions: market-preserving federalism and economic growth". Journal of Law, Economics and Organization, 11:1-31.

WHITE, Harrison. (1992), Identity and control. Princeton, Princeton University Press.

WILFRIED, Ettle e WIESENTAHL, Helmut. (1994), "Tarifautonomie in de-industrialisierten Gelande. Analyse eines institutionentransfers in Prozess der deutschen Einheit". Kölner Zeitschrift für Soziologie und Sozialpsyschologie, 40(3):425-452.

WILLIAMSON, John. (1994), "In search of a manual for Technopolis", in J. Williamson (org.), The political economy of policy reform, Washington, Institute for International Economics, pp.11-28.

* Conferência proferida por David Stark no XXI Encontro Anual da Anpocs, Caxambu, outubro de 1997. O trabalho é originário de David Stark e Laszlo Bruszt, Postsocialist pathways: transforming politics and property in Eastern Europe, Cambridge, Cambridge University Press, 1998. Tradução de Eduardo Cesar Marques. Revisão técnica de Argelina Cheibub Figueiredo.

I N. do T. - A palavra inglesa accountability foi traduzida aqui e em inúmeros outros pontos do texto porresponsabilidade política, embora essa última não dê conta dos múltiplos significados da primeira, cuja tradução direta não é possível na língua portuguesa. Ao contrário de responsabilidade, accountability é um atributo do sistema político, e não do governante, que a ele se impõe. Diz respeito não apenas à sua responsabilidade, mas à imposição, pelo sistema, de visibilidade e transparência nos atos do governo, assim como à responsabilização dos governantes pelos governados (inclusive com a possibilidade de sanções).

II N. do T. - O autor se refere à realização de uma análise da rede de firmas utilizando a metodologia de análise de redes sociais. Para uma descrição do estudo para o caso húngaro ver Stark (1996). A análise de redes sociais (social network analysis na literatura de língua inglesa ou analyse de réseaux sociaux na literatura de língua francesa) é uma metodologia relativamente recente cujo uso tem crescido e se expandido muito nos últimos anos. Através dela se tenta construir uma sociologia e uma política fortemente relacionais, que a partir de vínculos e ligações e da estrutura por elas construída, incluindo as posições ocupadas pelas entidades e indivíduos, estuda os fenômenos sociais mais variados. A utilização da metodologia pela literatura de língua portuguesa é até o momento praticamente inexistente.

III N. do T. - A palavra inglesa account, raiz de accountability (que está sendo traduzida aqui por responsabilidade política), tem múltiplos significados. É ao mesmo tempo o verbo "fazer a contabilidade" e o verbo "descrever", assim como o substantivo "conta bancária", além de estar presente em diferentes expressões como "o que conta" e "levar em conta". Neste parágrafo do texto os autores jogam com os vários sentidos da palavra para desenvolver seu raciocínio. Como a tradução literal é por vezes impossível, foram grafados em itálico os pontos onde foram utilizados no original palavras com esta raiz (e com este propósito). 